Article

\title{
Wear Transition of CrN Coated M50 Steel under High Temperature and Heavy Load
}

\author{
Chi Zhang ${ }^{1}{ }^{(D)}$, Le Gu ${ }^{1, *}$, Guangze Tang ${ }^{2}$ and Yuze Mao ${ }^{1}$ \\ 1 Research Lab of Space \& Aerospace Tribology, Harbin Institute of Technology, Harbin 150001, China; \\ zhc_hit@163.com (C.Z.); ma0yuze@163.com (Y.M.) \\ 2 School of Material Science and Technology, Harbin Institute of Technology, Harbin 150001, China; \\ tangoak@163.com \\ * Correspondence: gule@hit.edu.cn; Tel.: +86-451-8640-3712
}

Academic Editor: Shiladitya Paul

Received: 22 September 2017; Accepted: 15 November 2017; Published: 20 November 2017

\begin{abstract}
The combination of high temperature indentation and wear test provides a useful way to investigate wear of $\mathrm{CrN}$ coating and wear transition mechanisms. In this paper, the high temperature hardness of $\mathrm{CrN}$ coatings and load bearing capacity, $L_{\mathrm{b}}$, of $\mathrm{CrN}$ coated M50 disks were determined from spherical indentation at temperatures up to $500^{\circ} \mathrm{C}$. Wear tests with different normal loads were carried out at the same temperatures as the indentation tests. The results show that wear mechanism of $\mathrm{CrN}$ coating changes with external load, $P$, and temperature, $T$. Under a tested condition of $P<L_{\mathrm{b}}$ and $T<315{ }^{\circ} \mathrm{C}$, abrasive is the dominant wear mechanism for $\mathrm{CrN}$ coating. Under a tested condition of $P<L_{\mathrm{b}}$ and $T \geq 315{ }^{\circ} \mathrm{C}$, wear of $\mathrm{CrN}$ coating transitions into mild oxidation wear due to the lubricating effect of chromium oxide film. Under a tested condition of $P>L_{\mathrm{b}}$ and $T<315^{\circ} \mathrm{C}$, wear of $\mathrm{CrN}$ coating was controlled by coating fracture. Under a tested condition of $P>L_{\mathrm{b}}$ and $T \geq 315^{\circ} \mathrm{C}$, wear of $\mathrm{CrN}$ coating transitions into the severe wear mode, due to the tensile fracture of oxidation films, thereby leading to adhesion between $\mathrm{CrN}$ coating and tribo-counterpart. The presented method can be helpful in predicting permissible load and working temperature in tribological applications of CrN coating.
\end{abstract}

Keywords: $\mathrm{CrN}$ coating; high temperature indentation; high temperature mechanical properties; wear mechanism; wear transition

\section{Introduction}

Chromium nitride ( $\mathrm{CrN}$ ) films, with good oxidation, anti-corrosive and anti-adhesive properties [1-4], are promising candidates for protection in high temperature applications, such as for tools or aerospace rolling bearings. Nevertheless, the wear of such $\mathrm{CrN}$ coating-steel substrate systems at elevated temperatures is still not completely understood [5-8]. This is because the material removal process for $\mathrm{CrN}$ coatings is dependent on operation parameters (load, temperature, etc.). Wear mechanism for $\mathrm{CrN}$ coatings may be changed when the external load or working temperature are changed. Lim and Ashby [9] first suggested using the terms "wear transition" for describing the changing of dominant wear mechanisms with contact pressure and velocity in a steel tribo-pair. Later, Wang et al. [10] studied the wear transition for homogenous brittle materials, such as $\mathrm{Al}_{2} \mathrm{O}_{3}, \mathrm{Si}_{3} \mathrm{~N}_{4}$ and $\mathrm{SiC}$ ceramics. There is still a lack of information about the wear transition of $\mathrm{CrN}$ coatings. Therefore, the aim of this paper is to evaluate dependency of the wear of $\mathrm{CrN}$ coatings on both temperature and external load.

The wear transition from abrasive wear to oxidative wear was frequently observed for $\mathrm{CrN}$ coatings at high temperature. Polcar et al. [11] performed elevated temperature ball-on-disc tests on $\mathrm{CrN}$ coatings sliding against $\mathrm{Al}_{2} \mathrm{O}_{3}$ ball. It was found that the tribological properties of $\mathrm{CrN}$ coatings at high temperature were predominantly influenced by formation of a chromium oxide tribo-layer. Qi et al. [12] 
studied the tribo-oxide behavior of $\mathrm{CrN}$ and $\mathrm{Cr}_{2} \mathrm{~N}$ coatings. The dense $\mathrm{Cr}_{2} \mathrm{O}_{3}$ scales both formed on the $\mathrm{Cr}_{2} \mathrm{~N}$ and $\mathrm{CrN}$ coatings after tribological tests at temperatures above $300{ }^{\circ} \mathrm{C}$. Mandrino et al. [13] observed that the chromium-oxide films formed on CrN coatings were very thin (in 10-100 nm region). However, Scheerer et al. [14] argued that there may be critical loads, above which the lubricating of chromium oxide tribo-layer failed. He found that the high temperature wear of $\mathrm{CrN}$ coatings can be classified as oxidative mild wear under a low load, but different wear mechanisms under a high load, such as adhesive wear, delamination wear or the compound wear mechanisms containing oxidative wear and abrasive wear or adhesive wear. However, he did not further study how to determine the critical loads for a chosen $\mathrm{CrN}$ coating-substrate system.

By extension of the depth-sensing indentation techniques to elevated temperatures, the critical load for a coating-substrate system at high temperatures can be studied [15]. A comprehensive work on high-temperature sharp indentation has recently been presented by Smith et al. [16]. However, some researchers [17-19] argued that the indentation response was highly dependent on the tip geometry characteristic. As the oxidation of diamond is known to occur above $400{ }^{\circ} \mathrm{C}$, the geometric variation of indenter's diamond tip due to the asymmetric thermal expansion or erosion by oxidation is a serious concern at high temperatures. Using a tungsten carbide (WC) ball with high hardness and oxidation resistance as the indenter tip avoids any such geometric variation or erosion.

In this paper, a joint test rig, equipped with a $\phi 1.588 \mathrm{WC}$ ball as the indenter tip, was developed for performing both high temperature indentation tests and ball-on-disk tribological tests. Then, the indentation and wear tests on $\mathrm{CrN}$ (with different thickness) coated M50 disks were performed from $25^{\circ} \mathrm{C}$ to $500{ }^{\circ} \mathrm{C}$ in open atmosphere. Hardness, $H$, and load bearing capacity, $L_{\mathrm{b}}$, of $\mathrm{CrN}$ coated M50 disks at high temperatures were predicted by load-displacement measurements. Besides, post wear test examination revealed the relationships between applied loads and material removal patterns for $\mathrm{CrN}$ coated M50 disks at each temperatures. Based on these results, the wear transition mechanisms for $\mathrm{CrN}$ coated M50 disks were explored.

\section{Materials and Methods}

\subsection{M50 Disks and CrN Coatings}

The chemical composition of the as-received M50 disks was as follows (wt \%): C 0.72, Mn 0.3, Si 0.2, Cr 3.72, Mo 4.0, Ni 0.1, V 1.0, Cu 0.03 and Fe balanced. All of the M50 disks with $50 \mathrm{~mm}$ in diameter and $6 \mathrm{~mm}$ in thickness were polished to surface roughness, $R_{\mathrm{a}}$, of approximately $0.04 \mu \mathrm{m}$ and cleaned with alkaline in an ultrasonic bath, dried in warm air.

$\mathrm{CrN}$ coatings were deposited on M50 steel disks by the multi-arc ion plating technique, which were commercially available, provided by Beijing Technology Science Corp., Ltd. (Beijing, China). The M50 disks were mounted on a rotating table $(2 \mathrm{r} / \mathrm{min})$ at a distance of $180 \mathrm{~mm}$ from the arc source. The growth rate of was approximately $2 \mu \mathrm{m} / \mathrm{h}$, using the following process parameters: target material: two $\mathrm{Cr}$ targets with diameter $100 \mathrm{~mm}$ and $99.9 \%$ in purity being used as cathodes and placed oppositely with a distance of $460 \mathrm{~mm}$; atmosphere: Ar- $\mathrm{N}_{2}$ mixture with an $\mathrm{N}_{2}$-partial pressure of $2.4 \times 10^{-3} \mathrm{mbar}$ $(0.24 \mathrm{~Pa})$ and a total working pressure of $4 \times 10^{-3} \mathrm{mbar}(0.4 \mathrm{~Pa})$; bias: $-70 \mathrm{~V}$; temperature: $450{ }^{\circ} \mathrm{C}$. Coating thickness was controlled by the deposition time. The coating thickness of the two kinds of $\mathrm{CrN}$ coated M50 disks were around $2 \pm 0.2 \mu \mathrm{m}$ and $5 \pm 0.2 \mu \mathrm{m}$, corresponding to processing times of $60 \mathrm{~min}$ and $150 \mathrm{~min}$, respectively.

\subsection{Test Rig}

The joint test rig for high temperature micro-indentation and wear test was developed based on a Bruker CETR UMT-3 multifunction tribometer (Bruker, Billerica, MA, USA), as schematically shown in Figure 1. Balls of WC with a diameter of $1.588 \mathrm{~mm}$ and surface roughness, $R_{\mathrm{a}}$, of $0.02 \mu \mathrm{m}$ were used as the indenter tips and tribo-counterparts. The indented disk was fixed on specimen stage and heated by resistance heaters (labeled as H1) under the surface of stage. The thermocouple (labeled as T1) for 
controlling the sample temperature was placed $1 \mathrm{~mm}$ besides the disk. The thermocouple (labeled as T2) for measuring the indenter's temperature was located $2 \mathrm{~mm}$ from WC ball. The thermocouple (labeled as T3) for controlling chamber temperature was placed on the cover of chamber. The resistance heaters (labeled as $\mathrm{H} 2$ and $\mathrm{H} 3$ ) for heating chamber were placed around the wall. Besides, an air-cooling thermal shield was placed between the chamber and loading cell for minimization of any heating of electronics in the loading cell. During indentation tests or wear tests, the temperature differences among T1, T2, and T3 was ensured to be less than $5^{\circ} \mathrm{C}$.

a)

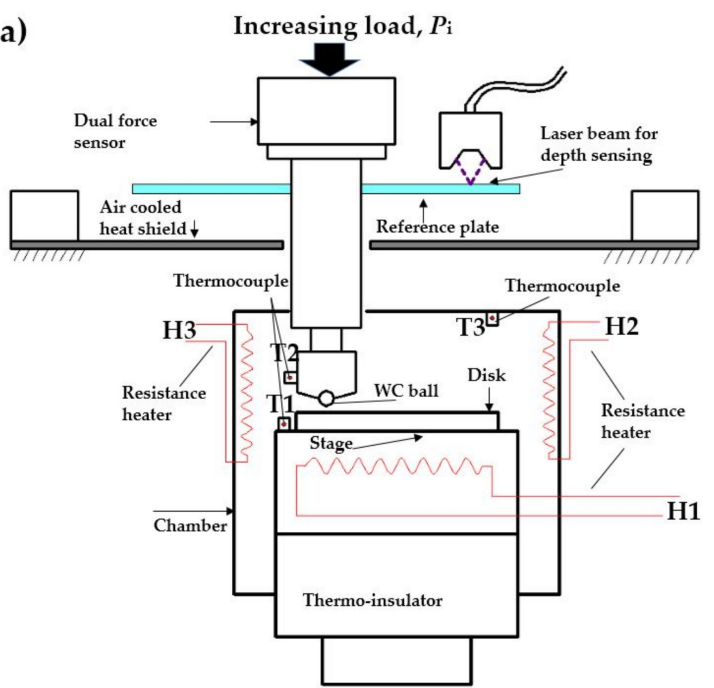

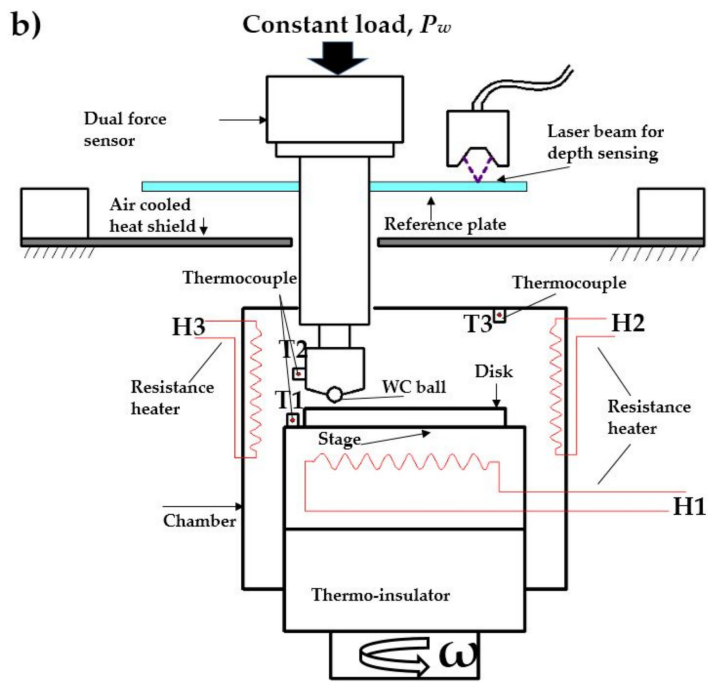

Figure 1. Schematic of the joint test rig for high temperature micro-indentation and wear test: (a) for indentation test; (b) for wear test.

In indentation tests, the stage was kept stationary. The WC ball was pressed against tested surface under an increasing load, $P_{\mathrm{i}}$, thus displacement occurred for the reference plate which was rigidly connected to the indenter, as shown in Figure 1a. The applied force, $P_{\mathrm{i}}$, was measured by the load sensor (UMT, DFH-100-44163, scale $1000 \mathrm{~N}$, resolution 0.01\%, Bruker, Billerica, MA, USA). The displacement of the reference plate was recorded by the CCD laser sensor (LK-G10, scale $\pm 1 \mathrm{~mm}$, resolution $0.02 \%$, Keyence, Osaka, Japan). In wear tests, the WC ball was pressed onto sample surface under a constant load, $P_{\mathrm{W}}$, while the table was rotated at the given speed, $\omega$.

\subsection{Test Procedure}

The parameters used in high temperature indentation and wear tests are shown in Table 1.

Table 1. Parameters used in high temperature indentation tests and wear tests.

\begin{tabular}{c|c|c|c}
\hline \multicolumn{2}{c|}{ Indentation Test } & \multicolumn{2}{c}{ Wear Test } \\
\hline Initial contact load & $1 \mathrm{~N}$ & Normal load & $10 \mathrm{~N}, 15 \mathrm{~N}, 25 \mathrm{~N}$ \\
Loading/unloading rate & $2 \mathrm{~N} / \mathrm{s}$ & Linear speed & $10.5 \mathrm{~mm} / \mathrm{s}$ \\
Peak load & $300 \mathrm{~N}$ & Revs & 900 \\
Holding load & In unloading stage at $30 \mathrm{~N}$ & & Temperature \\
Holding duration & $60 \mathrm{~s}$ & $25^{\circ} \mathrm{C}, 200^{\circ} \mathrm{C}, 315^{\circ} \mathrm{C}$, \\
Temperature & $25^{\circ} \mathrm{C}, 200^{\circ} \mathrm{C}, 315^{\circ} \mathrm{C}, 400^{\circ} \mathrm{C}, 500^{\circ} \mathrm{C}$ & & $400^{\circ} \mathrm{C}, 500^{\circ} \mathrm{C}$ \\
\hline
\end{tabular}

In the case of performing high temperature indentation tests, the WC ball was loaded against the tested surface at an initial load of $1 \mathrm{~N}$. After a stabilization period about $300 \mathrm{~s}$, the system was at thermal equilibrium. The loading and unloading rates were both $2 \mathrm{~N} / \mathrm{s}$. The peak load was $300 \mathrm{~N}$. There was an additional holding at $10 \%$ of peak load at unloading stage for thermal drift correction. Indentation tests were performed at $25^{\circ} \mathrm{C}, 200^{\circ} \mathrm{C}, 315^{\circ} \mathrm{C}, 400{ }^{\circ} \mathrm{C}$ and $500^{\circ} \mathrm{C}$ for all samples. Six repetitions were 
carried out at each temperature to confirm the repeatability. The experimental parameters for the wear tests were as follows: the normal loads of $10 \mathrm{~N}, 15 \mathrm{~N}$, and $25 \mathrm{~N}$; a linear speed of $10.5 \mathrm{~mm} / \mathrm{s}$; a total of 900 revs for each tests. Wear tests were also performed at $25^{\circ} \mathrm{C}, 200{ }^{\circ} \mathrm{C}, 315^{\circ} \mathrm{C}, 400{ }^{\circ} \mathrm{C}$ and $500{ }^{\circ} \mathrm{C}$ for all samples. After the wear tests, scanning electron microscope (SEM, Quanta2000, Philips, Amsterdam, The Netherlands) and energy dispersive X-ray spectroscopy (EDS, EDAX-7760/68 ME, Ametek, Berwyn, PA, USA) were used to evaluate the wear scars.

\subsection{Theoretical Background for Spherical Indentation}

The measured displacement of the reference plate consisted of contact interference between WC ball and indented samples, elastic deformation of the testing frame, and thermal drift. In the present study, the linearity correction method [20] was valid for eliminating the effects of thermal drift and elastic deformation of the testing frame.

Figure 2a shows a typical indentation load-depth curve. For high alloy steels that have significant "plastic pile-up" generated in material during indention process, Figure $2 \mathrm{~b}$ shows the typical indentation morphology by spherical indenter.

a)

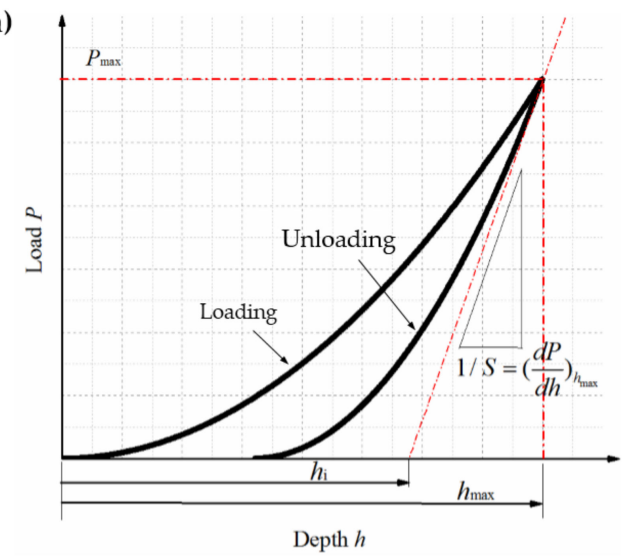

b)

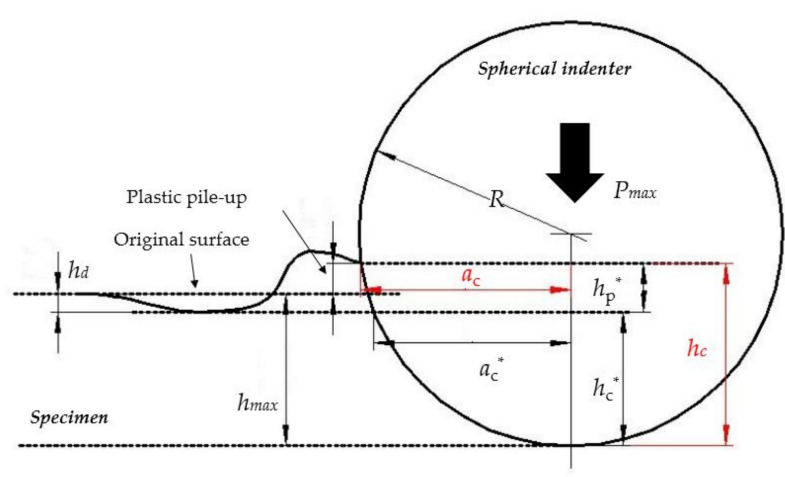

Figure 2. The typical load-depth curve and indentation morphology by spherical indenter: (a) the typical load-depth curve; (b) the typical indentation morphology by spherical indenter for steels.

As shown in Figure 2a, the maximum depth, $h_{\max }$, was the total displacement of the indented surface and the indenter at maximum load, $P_{\max }$. The slope of the unloading curve at $P_{\max }$ was the indentation stiffness of the specimen and indenter, noted as $1 / S$. The intercept depth, $h_{\mathrm{i}}$, was obtained by extrapolating the tangent line of the initial unloading curve to $P=0$. In addition, some indentation depths were defined from indentation morphology, as shown in Figure $2 b$. $h_{c}$ was the actual contact depth considering "plastic pile-up". $a_{\mathrm{c}}$ was the actual contact radius. The deflection depth, $h_{\mathrm{d}}$, was the depth to which the maximum indentation depth, $h_{\max }$, was reduced by elastic deflection of the indented material. The difference of $h_{\max }$ and $h_{\mathrm{d}}$ was the elastic contact depth, $h_{\mathrm{c}}{ }^{*}$. The increase in depth from $h_{\mathrm{c}}{ }^{*}$ to $h_{\mathrm{c}}$ by the "plastic pile-up" phenomenon was defined as $h_{\mathrm{p}}{ }^{*}$. Finally, the actual contact depth, $h_{\mathrm{c}}$, can be expressed as:

$$
h_{\mathrm{c}}=h_{\mathrm{c}}^{*}+h_{\mathrm{p}}^{*}=h_{\max }-h_{\mathrm{d}}+h_{\mathrm{p}}^{*}
$$

Kim et al. [21] studied the actual contact depth during spherical indentation of many kinds of tool steels. According to his study, the elastic contact depth, $h_{\mathrm{c}}{ }^{*}$, and the pile-up depth, $h_{\mathrm{p}}{ }^{*}$, could be expressed as:

$$
\begin{gathered}
h_{\mathrm{c}}^{*}=h_{\max }-h_{\mathrm{d}} \\
h_{\mathrm{d}}=\chi\left(h_{\max }-h_{\mathrm{i}}\right) \\
h_{\mathrm{p}}^{*} / h_{\mathrm{c}}^{*}=0.131\left(1-3.423 n+0.079 n^{2}\right) \times\left[1+6.258\left(h_{\max } / R\right)-8.072\left(h_{\max } / R\right)^{2}\right]
\end{gathered}
$$


where $x$ is a constant related to the indenter shape; $\chi=0.75$ for a spherical indenter. $n$ is the working-hardening exponent for indented material, and $n$ was set as 0.25 in the present study. $R$ was the radius of the ball. Then, the composite hardness, $H_{\text {sys }}$, and composite elastic modulus, $E_{\mathrm{r}}$, of the $\mathrm{CrN}$ coating-M50 substrate system were determined as follows:

$$
H_{\mathrm{sys}}=\frac{P_{\max }}{A}, A=\pi\left(2 R h_{\mathrm{c}}-h_{\mathrm{c}}^{2}\right)
$$

The composite hardness of coating-substrate system was thus the result of the two, coating and substrate, contributed. In order to determine the true hardness of the coating, it was necessary to separate these contributions. According to the model advanced by Puchi-Cabrera [22], the relationship between the composite hardness of coating-substrate system and the independent hardness of coating and substrate can be expressed as:

$$
H_{\mathrm{sys}}=H_{\mathrm{s}}+\left(H_{\mathrm{c}}-H_{\mathrm{s}}\right) \exp \left(-k Z_{\mathrm{r}}^{n}\right)
$$

where $H_{\mathrm{s}}$ is the substrate hardness. $H_{\mathrm{c}}$ is the coatings hardness. $Z_{\mathrm{r}}$ is the relative indentation depth, and $Z_{\mathrm{r}}=2 a_{\mathrm{c}} / 7 t_{c} . t_{\mathrm{c}}$ is the coating thickness. $k$ and $n$ are the constants characteristic of the coating-substrate system. Puchi-Cabrera [22] studied the indentation response of the $\mathrm{CrN}$ coated tool steel. According to his study, $k$ and $n$ were determined to be 2.3 and 0.25 , respectively.

\section{Results}

\subsection{Indentation Tests at Elevated Temperatures}

Elevated temperature indentation test results of uncoated M50 disks, $2 \mu \mathrm{m}$ CrN coated M50 disks and $5 \mu \mathrm{m} \mathrm{CrN}$ coated ones are shown in Figure 3.
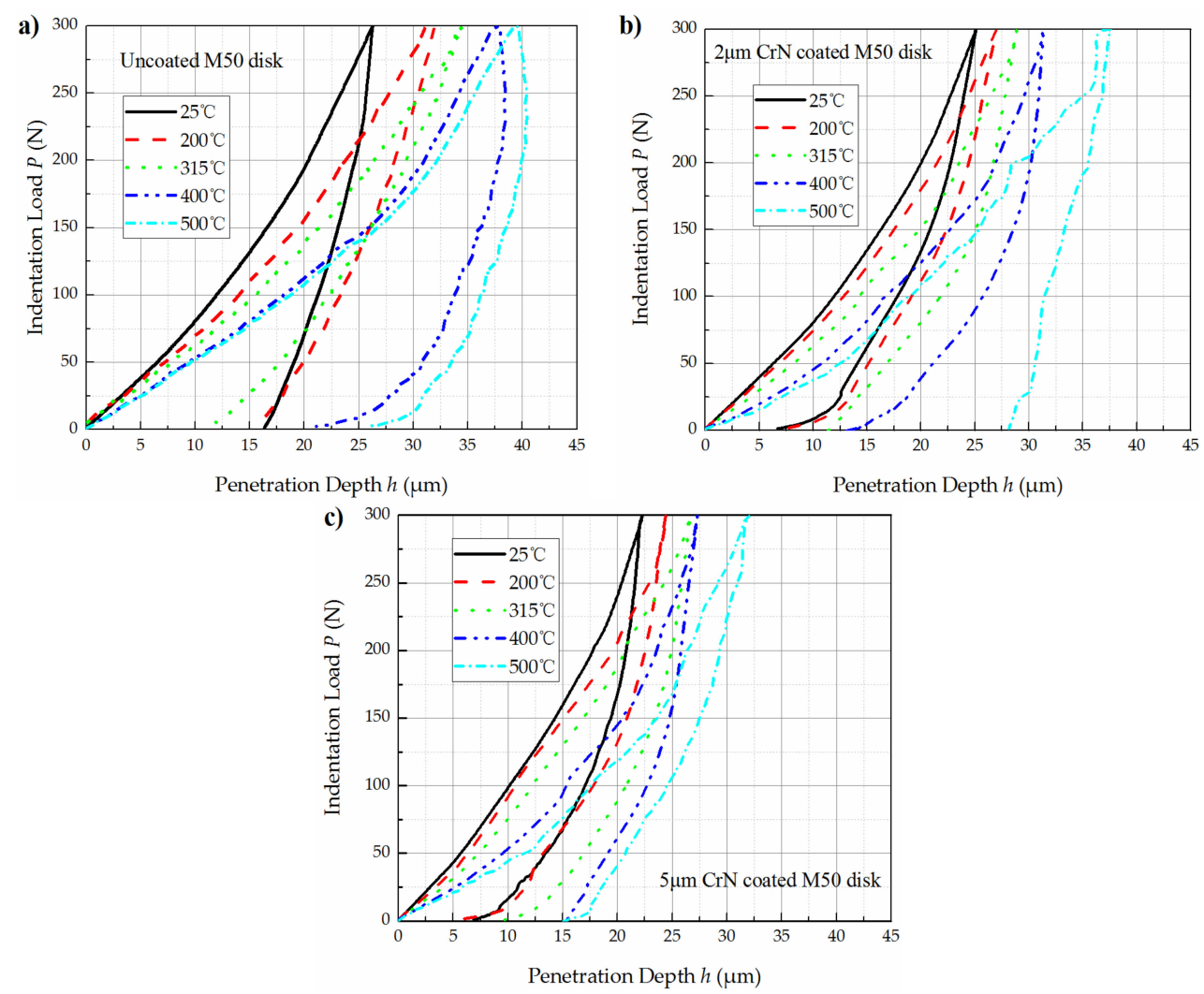

Figure 3. Load-depth curves of the samples as a function of temperatures: (a) uncoated M50 disk; (b) $2 \mu \mathrm{m} \mathrm{CrN} \mathrm{coated} \mathrm{M50} \mathrm{disk;} \mathrm{and} \mathrm{(c)} 5 \mu \mathrm{m}$ CrN coated M50 disk. 
Using Equations (1)-(5), hardness of M50 substrate, $H_{\mathrm{s}}$, and composite hardness of $\mathrm{CrN}$ coated M50 disks, $H_{\text {sys }}$, were calculated from the load-depth curve shown Figure 3. Then, using Equation (6), the absolute hardness of $2 \mu \mathrm{m} \mathrm{CrN}$ coating and $5 \mu \mathrm{m} \mathrm{CrN}$ coating were calculated, as presented in Figure 4. In general, $\mathrm{CrN}$ coatings with all thicknesses showed a decreasing of hardness with temperatures. When the tested temperature was below $315^{\circ} \mathrm{C}$, the hardness of $2 \mu \mathrm{m}$ thick $\mathrm{CrN}$ coating was higher than $5 \mu \mathrm{m}$ thick $\mathrm{CrN}$ coating. However, when the tested temperature was above $400{ }^{\circ} \mathrm{C}$, the $5 \mu \mathrm{m}$ thick $\mathrm{CrN}$ coating had higher values in hardness. The $2 \mu \mathrm{m}$ thick $\mathrm{CrN}$ coating had reduction of $49 \%$ in hardness values when the temperature increased from 25 to $500{ }^{\circ} \mathrm{C}$. By comparison, the $5 \mu \mathrm{m}$ thick $\mathrm{CrN}$ coating only had a reduction of $26 \%$. It can be concluded that a thicker $\mathrm{CrN}$ coating would be helpful in maintaining the stability of surface hardness in high temperatures.

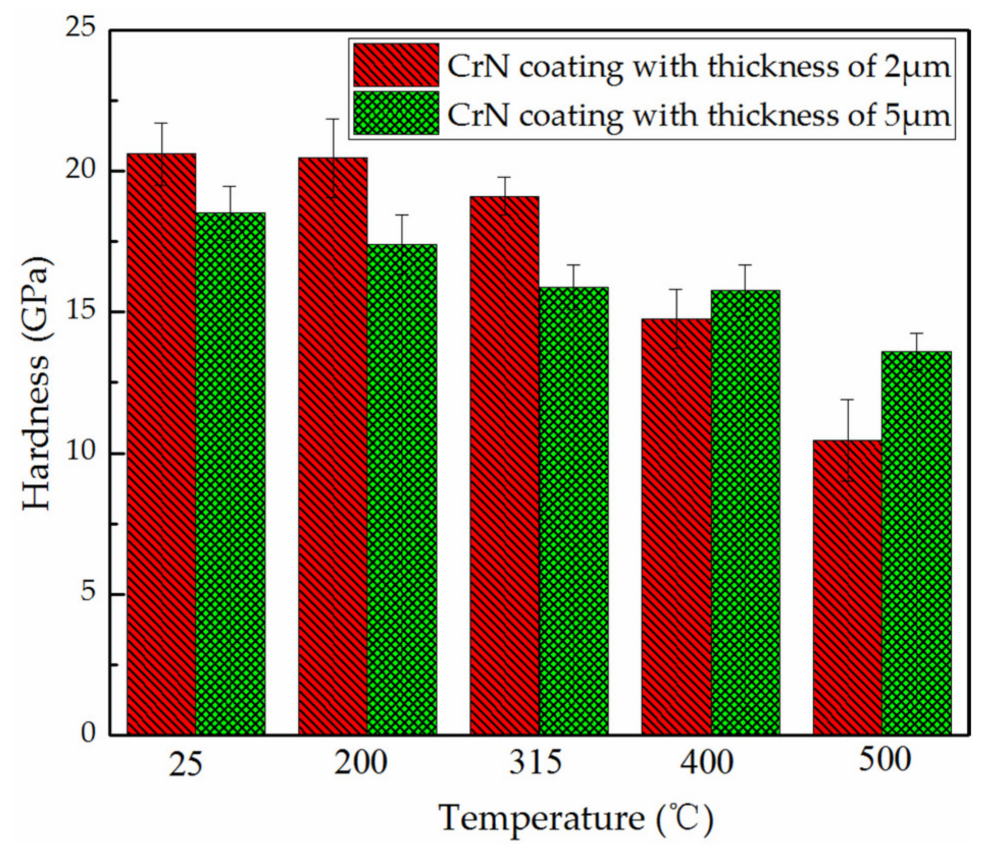

Figure 4. Hardness of $\mathrm{CrN}$ coating as a function of temperatures.

Figure 5 presents the loading curves and corresponding contact stress curves of $2 \mu \mathrm{m} C r N$ coated M50 disks and $5 \mu \mathrm{m} \mathrm{CrN} \mathrm{coated} \mathrm{ones} \mathrm{in} \mathrm{the} \mathrm{load} \mathrm{range} \mathrm{of} \mathrm{1-50} \mathrm{N.} \mathrm{The} \mathrm{contact} \mathrm{stress} \mathrm{during} \mathrm{indentation}$ tests can be calculated using the following equation [23]:

$$
\sigma=\frac{P}{\pi a_{\mathrm{c}}^{2}}
$$

where $\sigma$ is mean contact stress, and $a_{\mathrm{c}}$ is the contact radius during indentation.

In Figure $5 a, c$, the loading curves were continuous up to a certain load, at which a sudden displacement burst occurred, indicating the occurrence of "pop-in" behavior. According to Shao [24], the indentation stress-induced phase transition with material volume reduction (i.e., coating cracking) was the prerequisite to "pop-in" behavior. Hence, the indentation load, corresponding to the appearance of a "pop-in" event, could possibly be considered as an evaluation tool of load bearing capacity for the coating-substrate system. In another aspect, as shown in Figure 5b,d, it was found that the contact stress reached its maximum values at this indentation load. The external load corresponding to the "pop-in" behavior was named as the load bearing capacity, $L_{\mathrm{b}}$, for a coating-substrate system.

It can be concluded that the load bearing capacities of $\mathrm{CrN}$ coated M50 disks decreased with temperatures. As illustrated in Figure 5a,b, for the $2 \mu \mathrm{m} \mathrm{CrN}$ coated M50 disks, a normal load of $10 \mathrm{~N}$ was always less than its load bearing load bearing capacity, $L_{\mathrm{b}}$, in temperature range of $25-500{ }^{\circ} \mathrm{C}$. However, an external load of $15 \mathrm{~N}$ was higher than its load bearing capacity when the temperature 
was elevated to $500{ }^{\circ} \mathrm{C}$. An external load of $25 \mathrm{~N}$ was always higher than its load bearing capacity at any temperature. As illustrated in Figure $5 \mathrm{c}, \mathrm{d}$, for the $5 \mu \mathrm{m}$ CrN coated M50 disks, an external load of $10 \mathrm{~N}, 15 \mathrm{~N}$ or $25 \mathrm{~N}$ was always less than its load bearing capacity in temperature range of $25-500{ }^{\circ} \mathrm{C}$.
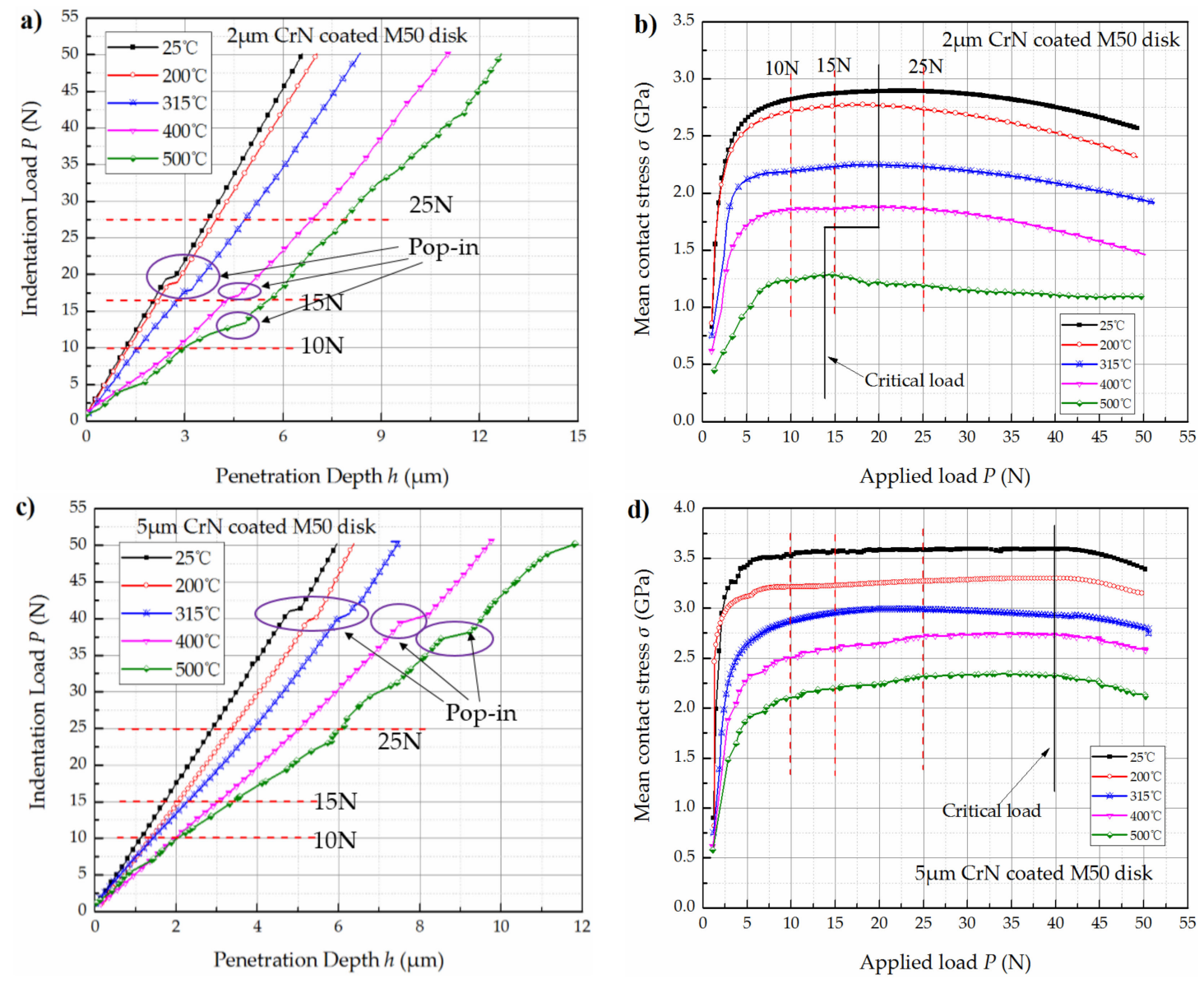

Figure 5. Loading curves and corresponding contact stress curves of the samples as a function of temperatures in the load range of 1-50 N: (a) loading curves of $2 \mu \mathrm{m}$ CrN coated M50 disk; (b) contact stress curves of $2 \mu \mathrm{m}$ CrN coated M50 disk; (c) loading curves of $5 \mu \mathrm{m} \mathrm{CrN} \mathrm{coated} \mathrm{M50} \mathrm{disk;}$ and (d) contact stress curves of $5 \mu \mathrm{m} \mathrm{CrN} \mathrm{coated} \mathrm{M50} \mathrm{disk.}$

\subsection{Tribological Responses}

Figure 6a-f shows the friction coefficient curves and penetration depth during wear test of $5 \mu \mathrm{m}$ $\mathrm{CrN}$ coated M50 disks as a function of temperatures under the tested loads of $10 \mathrm{~N}, 15 \mathrm{~N}$, and $25 \mathrm{~N}$. The variation of width of wear scars with temperatures is depicted in Figure $6 \mathrm{~g}$.

As illustrated in Figure $6 \mathrm{a}, \mathrm{c}, \mathrm{e}$, running-in was presented by an increase of the friction coefficient during first several dozens to hundreds of cycles for all measured temperatures and loads. In the running-in stage, the friction force is mainly contributed to deform and fracture the contact asperities [25]. Due to the lower hardness of the coating material at higher tested temperature, it would take less number of cycles for the friction coefficient to reach the steady stage.

For $5 \mu \mathrm{m}$ CrN coated M50 disks tested under each load, the stable values of friction coefficient were all found to be decreased with temperatures. At the temperatures of $25^{\circ} \mathrm{C}$ and $200{ }^{\circ} \mathrm{C}$, the friction coefficient was determined to be about 0.6 . However, it decreased to 0.4 at $315{ }^{\circ} \mathrm{C}$, then gradually decreased to the lowest value of 0.3 at the highest temperature of $500{ }^{\circ} \mathrm{C}$. 

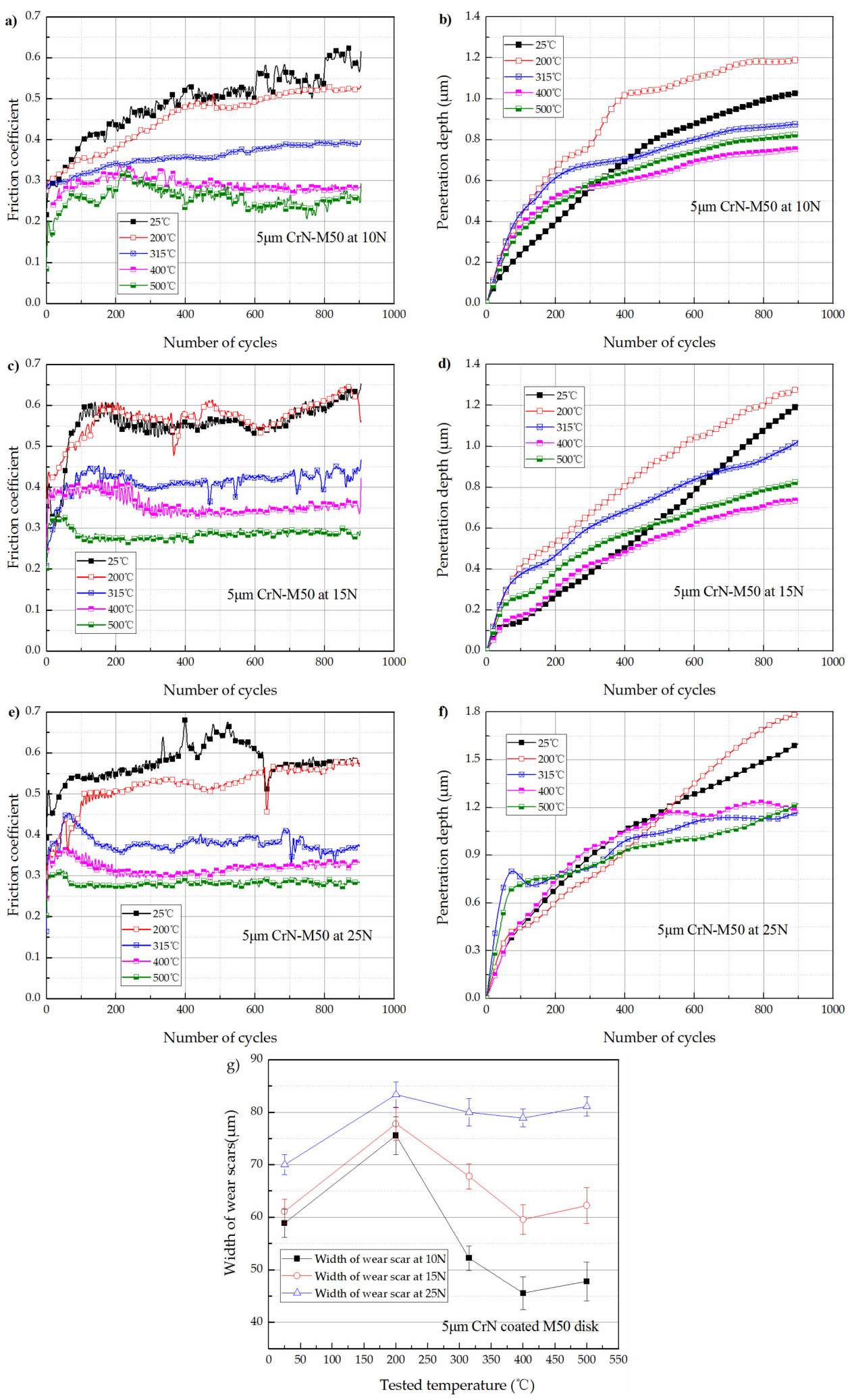

Figure 6. Friction coefficient curves and penetration depth during wear test of the $5 \mu \mathrm{m} \mathrm{CrN} \mathrm{coated}$ M50 disks: (a) variation of friction coefficient with temperatures under $10 \mathrm{~N}$; (b) variation of penetration depth with temperatures under $10 \mathrm{~N}$; (c) variation of friction coefficient with temperatures under $15 \mathrm{~N}$; (d) variation of penetration depth with temperatures under $15 \mathrm{~N}$; (e) variation of friction coefficient with temperatures under $25 \mathrm{~N}$; (f) variation of penetration depth with temperatures under $25 \mathrm{~N}$; and $(\mathrm{g})$ variation of width of wear scars with temperatures. 
As shown in Figure $6 \mathrm{~b}, \mathrm{~d}, \mathrm{f}$, the variation trends of penetration depth at the temperatures above $315{ }^{\circ} \mathrm{C}$ were quite different from those at the temperatures below $200{ }^{\circ} \mathrm{C}$. Due to the lower hardness of $\mathrm{CrN}$ coating at high temperatures, the penetrate depth increased more sharply at the temperatures above $315^{\circ} \mathrm{C}$ than at the temperature below $200{ }^{\circ} \mathrm{C}$ in first 300 cycles. After 300 cycles of relative sliding, the penetration depth went on increasing linearly with distance at the temperatures below $20{ }^{\circ} \mathrm{C}$, however, was much slowed down the temperatures above $315^{\circ} \mathrm{C}$. Meanwhile, the fluctuation in friction coefficient with sliding distance was also weakened when the tested temperatures were equal or above $315^{\circ} \mathrm{C}$. According to Polcar [11], the reduction of penetration depth at the temperatures above $315{ }^{\circ} \mathrm{C}$ might contributed to the self-lubricant function of the formed chromium oxide tribo-layer.

The high temperature tribological response of $2 \mu \mathrm{m} \mathrm{CrN} \mathrm{coated} \mathrm{M50} \mathrm{disks} \mathrm{under} \mathrm{each} \mathrm{tested}$ loads were quite different from the $5 \mu \mathrm{m} \mathrm{CrN} \mathrm{coated} \mathrm{M50} \mathrm{disks.} \mathrm{Figure} \mathrm{7a-f} \mathrm{shows} \mathrm{the} \mathrm{friction}$ coefficient curves and penetration depth during wear test of $2 \mu \mathrm{m} \mathrm{CrN} \mathrm{coated} \mathrm{M50} \mathrm{disks} \mathrm{as} \mathrm{a} \mathrm{function}$ of temperatures under the tested loads of $10 \mathrm{~N}, 15 \mathrm{~N}$ and $25 \mathrm{~N}$. The variation of width of wear scars with temperatures is depicted in Figure $7 \mathrm{~g}$.

As shown in Figures $6 \mathrm{a}$ and $7 \mathrm{a}$, under the tested load of $10 \mathrm{~N}$, the stable values of friction coefficients of $2 \mu \mathrm{m}$ CrN coated M50 samples were similar to those of the $5 \mu \mathrm{m}$ CrN coated M50 samples at each tested temperatures. As shown in Figure 7c, under the applied load of $15 \mathrm{~N}$, the friction coefficients of $2 \mu \mathrm{m} \mathrm{CrN} \mathrm{coated} \mathrm{M50} \mathrm{samples} \mathrm{were} \mathrm{still} \mathrm{similar} \mathrm{to} \mathrm{those} \mathrm{for} \mathrm{the} 5 \mu \mathrm{m} \mathrm{CrN} \mathrm{coated}$ M50 samples when the tested temperatures were equal or below $400{ }^{\circ} \mathrm{C}$. However, at the tested temperature of $500{ }^{\circ} \mathrm{C}$, the friction coefficient substantially increased from 0.25 to 0.55 during the wear test. As shown in Figure 7e, under the applied load of $25 \mathrm{~N}$, the values of friction coefficients at each temperatures were all above 0.5. As shown in Figure 7g, the width of wear scars was found to be always increased with the tested temperatures under the tested load of $25 \mathrm{~N}$.
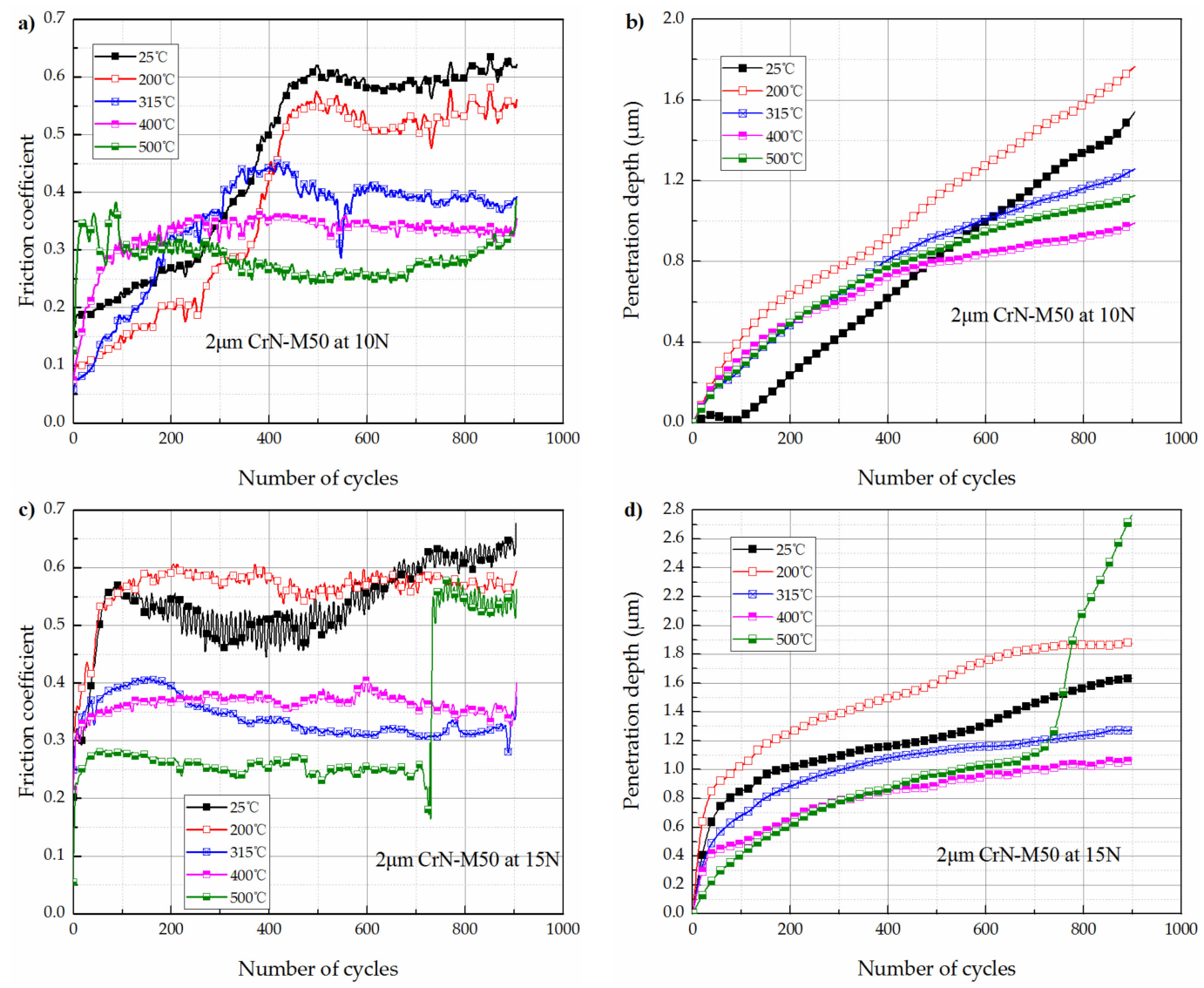

Figure 7. Cont. 

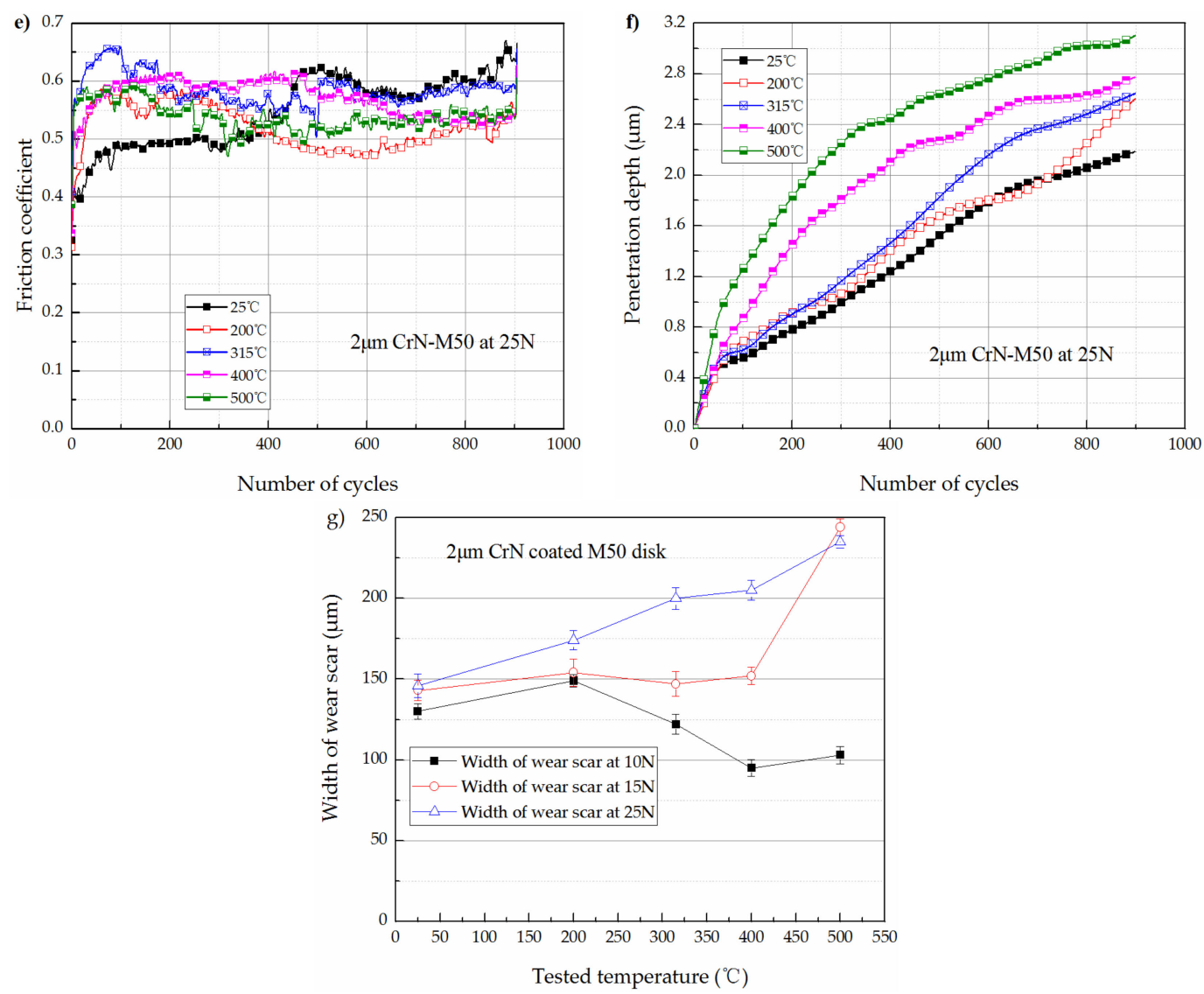

Figure 7. Friction coefficient curves and penetration depth during wear test of the $2 \mu \mathrm{m} \mathrm{CrN} \mathrm{coated}$ M50 disks: (a) variation of friction coefficient with temperatures under $10 \mathrm{~N}$; (b) variation of penetration depth with temperatures under $10 \mathrm{~N}$; (c) variation of friction coefficient with temperatures under $15 \mathrm{~N}$; (d) variation of penetration depth with temperatures under $15 \mathrm{~N}$; (e) variation of friction coefficient with temperatures under $25 \mathrm{~N}$; (f) variation of penetration depth with temperatures under $25 \mathrm{~N}$; and $(\mathrm{g})$ variation of width of wear scars with temperatures.

As shown in Figure 7b, the variation trends of penetration depth with temperatures of $2 \mu \mathrm{m}$ $\mathrm{CrN}$ coated M50 samples was similar to $5 \mu \mathrm{m}$ CrN coated ones. As shown in Figure $7 \mathrm{~d}$, when the tested load was increased to $15 \mathrm{~N}$ which was above the load bearing capacity of the $2 \mu \mathrm{m} \mathrm{CrN}$ coated M50 disks at $500{ }^{\circ} \mathrm{C}$, the penetration depth substantially increased at about 700 cycles. It should be noted that the friction coefficient was also substantially increased at about 700 cycles. As shown in Figure $7 \mathrm{f}$, under an applied load of $25 \mathrm{~N}$ which exceed the load bearing capacity of the $2 \mu \mathrm{m} \mathrm{CrN}$ coated M50 disks at any tested temperatures, the wear reduction function of chromium oxide tribo-layer failed. It can be observed that the wear rate always increased with temperatures under the load of $25 \mathrm{~N}$ for the $2 \mu \mathrm{m} \mathrm{CrN}$ coated M50 disks.

\subsection{Morphology and EDS Results of Worn Surfaces}

Figure 8 showed the morphology of worn tracks on $5 \mu \mathrm{m} \mathrm{CrN} \mathrm{coated} \mathrm{M50} \mathrm{disks} \mathrm{under} \mathrm{various}$ loads at the temperatures of $25{ }^{\circ} \mathrm{C}$ and $200{ }^{\circ} \mathrm{C}$. Small pits, narrow grooves parallel to the sliding direction, and wear debris were detected on the worn surfaces. EDS was used to identify the chemical compositions in different zones, and the results are listed in Table 2.

The EDS analysis results (at.\%) revealed that the worn tracks contained primarily $\mathrm{Cr}$ and $\mathrm{N}$ after 900 cycles of relative sliding at $25^{\circ} \mathrm{C}$ or $200{ }^{\circ} \mathrm{C}$. More importantly, a few W were detected in the worn tracks. It can be confirmed that slight material removal occurred for $\mathrm{CrN}$ coatings and WC ball 
during wear testing at $25^{\circ} \mathrm{C}$ and $200{ }^{\circ} \mathrm{C}$, indicating that the dominant wear mechanism at these two temperatures was mild abrasive wear.
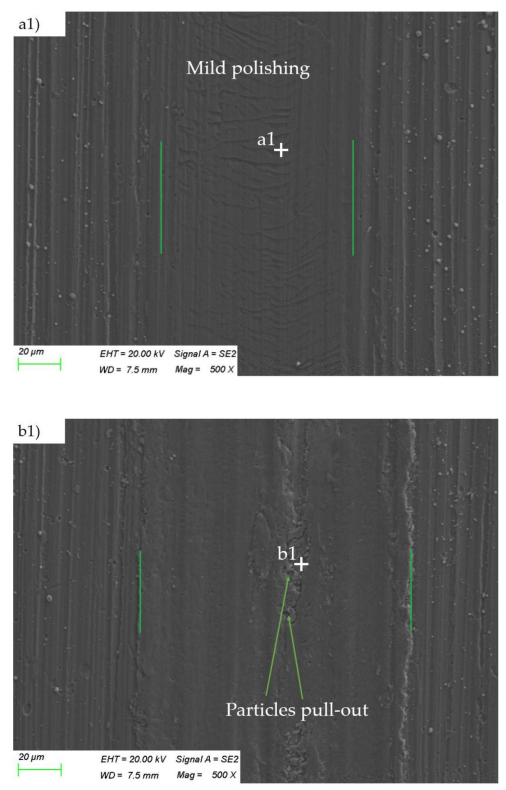

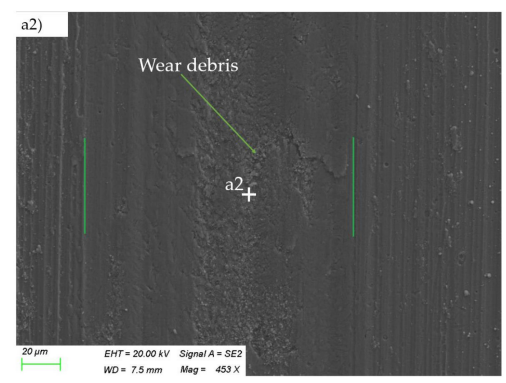

(a)

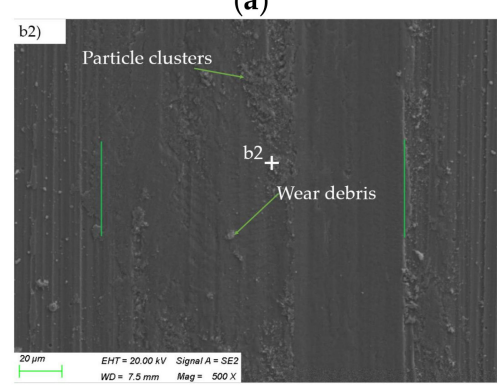

(b)
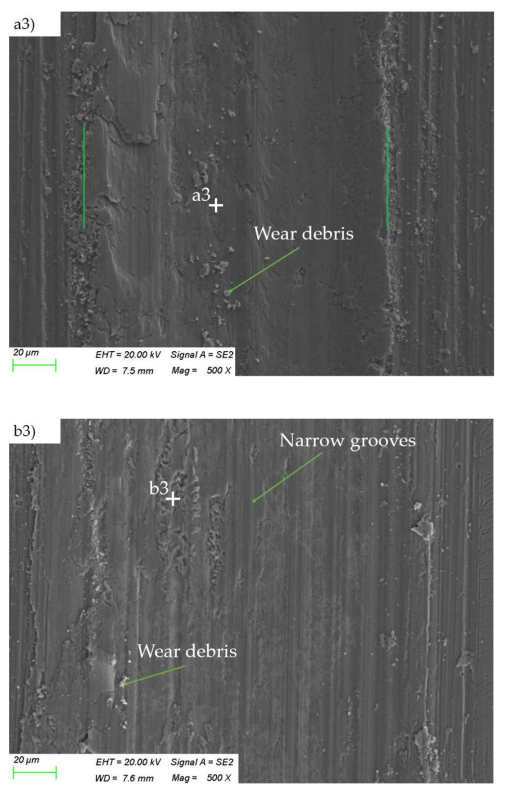

Figure 8. Morphology of the worn tracks on $5 \mu \mathrm{m} \mathrm{CrN} \mathrm{coated} \mathrm{M50} \mathrm{disks:} \mathrm{(a)} \mathrm{at} \mathrm{the} \mathrm{temperature} \mathrm{of}$ $25{ }^{\circ} \mathrm{C}$ under the load of (a1) $10 \mathrm{~N},(\mathbf{a} 2) 15 \mathrm{~N}$, and (a3) $25 \mathrm{~N}$; and (b) at the temperature of $200{ }^{\circ} \mathrm{C}$ under the load of (b1) $10 \mathrm{~N},(\mathbf{b} 2) 15 \mathrm{~N}$, and (b3) $25 \mathrm{~N}$.

Table 2. The EDS analysis results corresponding to the positions in Figure 8.

\begin{tabular}{ccccccc}
\hline \multirow{2}{*}{ Element, at.\% } & \multicolumn{7}{c}{ Positions } \\
\cline { 2 - 7 } & $\mathbf{a 1}$ & $\mathbf{a 2}$ & $\mathbf{a 3}$ & $\mathbf{b 1}$ & $\mathbf{b 2}$ & $\mathbf{b 3}$ \\
\hline $\mathrm{Cr}$ & 40.12 & 42.43 & 36.92 & 44.34 & 46.42 & 35.02 \\
$\mathrm{~N}$ & 47.68 & 38.06 & 35.21 & 31.8 & 38.68 & 30.14 \\
$\mathrm{O}$ & 2.33 & 6.06 & 8.77 & 7.98 & 6.92 & 10.37 \\
$\mathrm{Fe}$ & 1.7 & 4.53 & 5.89 & 11.87 & 0.93 & 7.96 \\
$\mathrm{~W}$ & 5.3 & 7.64 & 14.11 & 5.15 & 6.71 & 16.10 \\
\hline
\end{tabular}

In addition to the decreasing of friction coefficient, the morphology of worn tracks at the temperatures above $315^{\circ} \mathrm{C}$ was also much different from those at the temperatures below $315^{\circ} \mathrm{C}$. Figure 9 shows the morphology of wear tracks on $5 \mu \mathrm{m} \mathrm{CrN} \mathrm{coated} \mathrm{M50} \mathrm{disks} \mathrm{when} \mathrm{the} \mathrm{temperatures}$ were equal or above $315^{\circ} \mathrm{C}$. In Figure $9 \mathrm{a}$, it can be noticed that the worn tracks were quite smooth after sliding at $315{ }^{\circ} \mathrm{C}$ for 900 cycles under each tested loads. In Figure $9 \mathrm{~b}, \mathrm{c}$, it can be noticed that the worn surfaces were roughened with oxidized clusters. However, small pits, narrow grooves, and wear debris almost disappeared on the worn surfaces. SEM observation of wear tracks confirmed the existence of tribo-layers with lamellae structure over the worn tracks when wear tests on $\mathrm{CrN}$ coatings were performed at the temperatures above $315^{\circ} \mathrm{C}$.

EDS analysis results are listed in Table 3. It can be observed that the $\mathrm{O}$ contents approached or surpassed that of $\mathrm{N}$ in the worn area after 900 cycles of relative sliding at $315{ }^{\circ} \mathrm{C}, 400{ }^{\circ} \mathrm{C}$ or $500{ }^{\circ} \mathrm{C}$. Meanwhile, the worn area contained primarily $\mathrm{Cr}$ and $\mathrm{O}$. This meant that a mass of tribo-oxides formed on worn surfaces. As referred above [12], the oxidation of PVD CrN coating material started at the temperature around $300{ }^{\circ} \mathrm{C}$. More importantly, a few $\mathrm{W}$ were detected in the worn area, indicating that the oxide film can prevent the adhesion between $\mathrm{CrN}$ coating and $\mathrm{WC}$ ceramic ball and possess 
self-lubricant function. Thus, the friction coefficient and width of wear scars decreased at $315^{\circ} \mathrm{C}$. It is clear that wear of $\mathrm{CrN}$ coating at temperatures equal or above $315^{\circ} \mathrm{C}$ was mild oxidative wear.
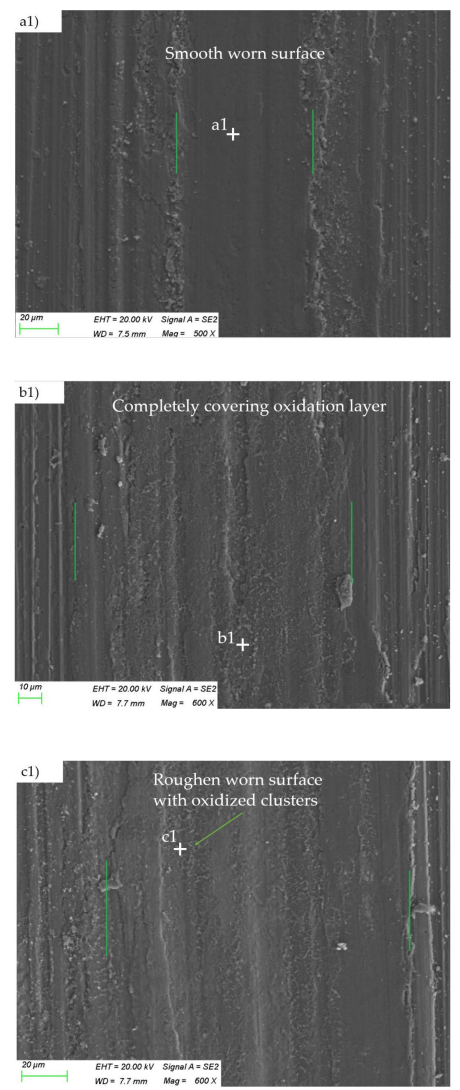

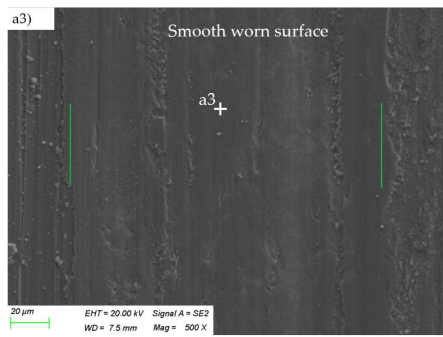

(a)

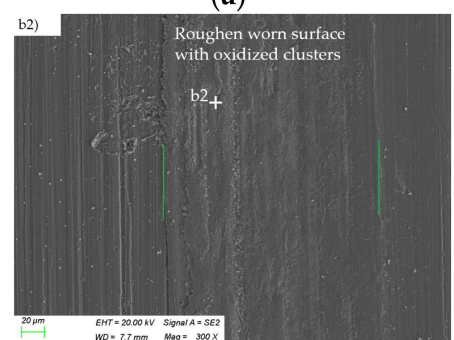

(b)

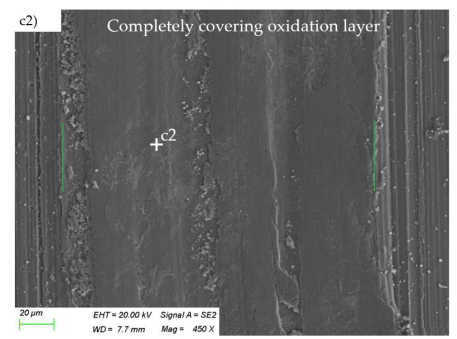

(c)
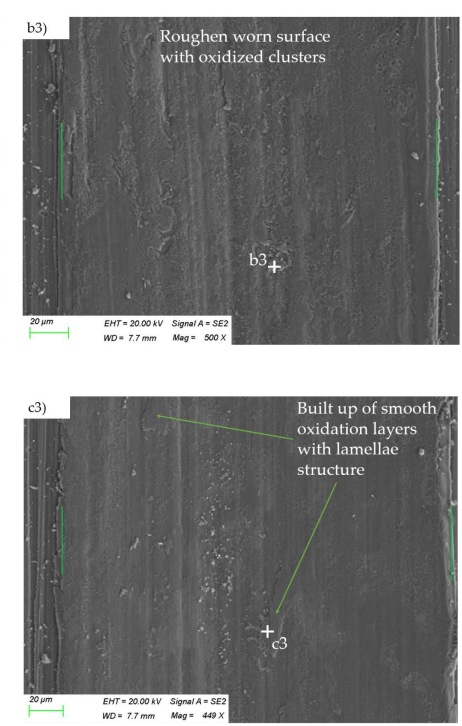

Figure 9. Morphology of the worn tracks on $5 \mu \mathrm{m} \mathrm{CrN} \mathrm{coated} \mathrm{M50} \mathrm{disks:} \mathrm{(a)} \mathrm{at} \mathrm{the} \mathrm{temperature} \mathrm{of}$ $315^{\circ} \mathrm{C}$ under the load of (a1) $10 \mathrm{~N},(\mathbf{a} 2) 15 \mathrm{~N}$, and (a3) $25 \mathrm{~N}$; (b) at the temperature of $400{ }^{\circ} \mathrm{C}$ under the load of (b1) $10 \mathrm{~N},(\mathbf{b} 2) 15 \mathrm{~N}$, and (b3) $25 \mathrm{~N}$; and (c) at the temperature of $500{ }^{\circ} \mathrm{C}$ under the load of (c1) $10 \mathrm{~N},($ c2 $) 15 \mathrm{~N}$, and (c3) $25 \mathrm{~N}$.

Table 3. The EDS analysis results corresponding to the positions in Figure 9.

\begin{tabular}{cccccccccc}
\hline & \multicolumn{10}{c}{ Positions } \\
\cline { 2 - 11 } Element, at.\% & $\mathbf{a 1}$ & $\mathbf{a 2}$ & $\mathbf{a 3}$ & $\mathbf{b 1}$ & $\mathbf{b 2}$ & $\mathbf{b 3}$ & $\mathbf{c 1}$ & $\mathbf{c 2}$ & $\mathbf{c 3}$ \\
\hline $\mathrm{Cr}$ & 46.39 & 46.23 & 36.6 & 30.19 & 36.2 & 37.99 & 38.36 & 35.08 & 32.35 \\
$\mathrm{~N}$ & 23.72 & 21.95 & 25.67 & 17.75 & 13.61 & 21.28 & 13.65 & 11.61 & 7.88 \\
$\mathrm{O}$ & 22.43 & 25.61 & 30.58 & 37.97 & 44.96 & 38.38 & 41.51 & 44.98 & 51.35 \\
$\mathrm{Fe}$ & 4.19 & 5.39 & 6.34 & 12.43 & 3.39 & 2.02 & 3.87 & 6.47 & 5.81 \\
$\mathrm{~W}$ & 0.07 & 0.04 & 0.05 & - & - & - & - & - & - \\
\hline
\end{tabular}

It can be concluded that, for $5 \mu \mathrm{m} \mathrm{CrN} \mathrm{coated} \mathrm{M50} \mathrm{disks,} \mathrm{the} \mathrm{dominant} \mathrm{wear} \mathrm{mechanism} \mathrm{transitioned}$ from mild abrasive wear to mild oxidation wear when the temperatures were above $315{ }^{\circ} \mathrm{C}$.

Figure 10 presents the morphology of worn tracks on $2 \mu \mathrm{m} \mathrm{CrN} \mathrm{coated} \mathrm{M50} \mathrm{disks} \mathrm{under} \mathrm{various}$ loads at the temperatures of $25^{\circ} \mathrm{C}$ and $200{ }^{\circ} \mathrm{C}$. As shown in Figure 10a1,a2,b1,b2, under the applied load of $10 \mathrm{~N}$ or $15 \mathrm{~N}$, the worn tracks on $2 \mu \mathrm{m} \mathrm{CrN} \mathrm{coated} \mathrm{M50} \mathrm{disks} \mathrm{and} \mathrm{the} \mathrm{worn} \mathrm{tracks} \mathrm{on}$ $5 \mu \mathrm{m}$ CrN coated M50 disks presented similar morphology. The dominant wear mechanism for the $2 \mu \mathrm{m}$ CrN coated M50 samples under the applied load of $10 \mathrm{~N}$ or $15 \mathrm{~N}$ was mild abrasive wear, corresponding to smooth worn surfaces with wear debris and narrow grooves presented in the worn area. However, when the load was increased to $25 \mathrm{~N}$, local coating fracture can be observed on the 
edge of the wear scars for the $2 \mu \mathrm{m}$ CrN coated M50 disks, as illustrated in Figure 10a3,b3. EDS analysis results are listed in Table 4. EDS analysis of the coating delamination area (Points a3, b3) confirmed the significant increasing of Fe element, indicating the partial detachment of coating material. The results above indicated that, at lower tested temperatures, the wear of $\mathrm{CrN}$ coatings transitioned from mild abrasive wear to the coating fracture controlled wear when the applied load exceeded its the load carrying capacity.
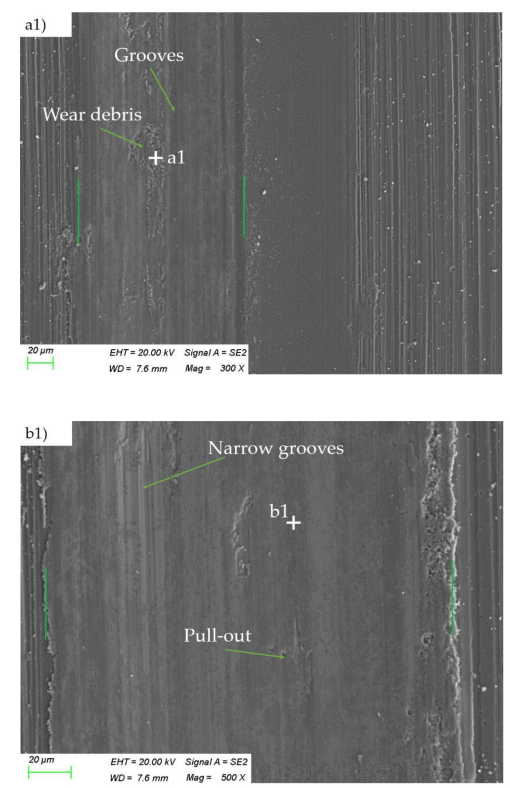

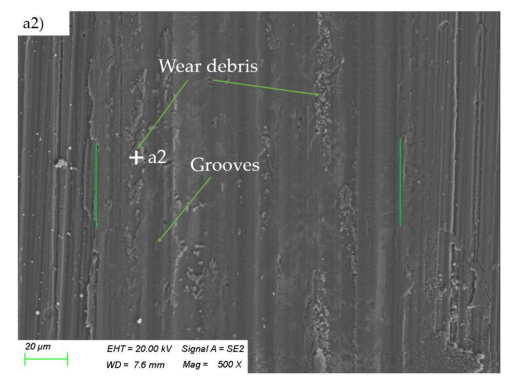

(a)

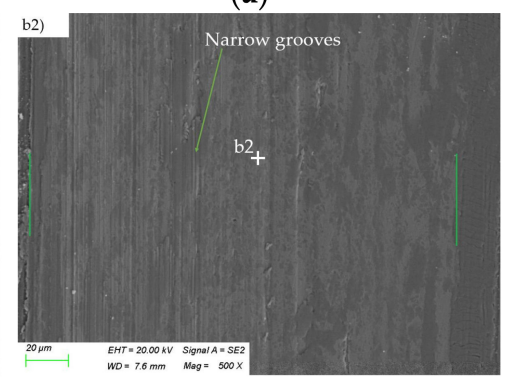

(b)
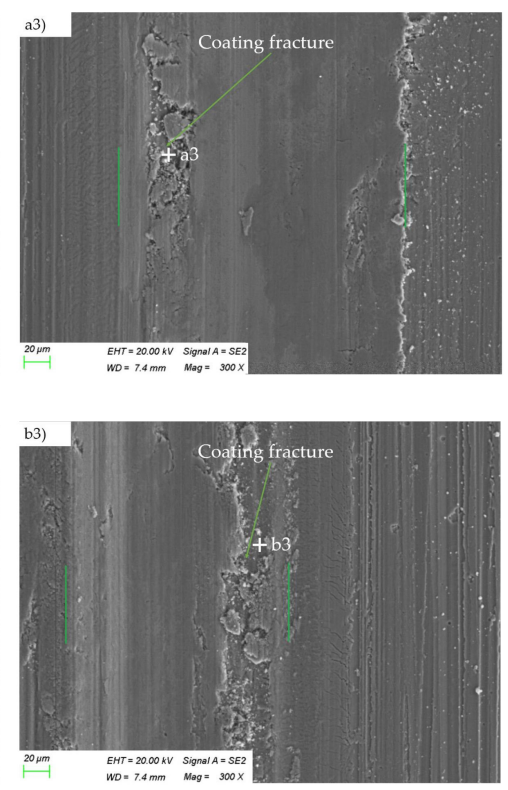

Figure 10. Morphology of the worn tracks on $2 \mu \mathrm{m} \mathrm{CrN} \mathrm{coated} \mathrm{M50} \mathrm{disks:} \mathrm{(a)} \mathrm{at} \mathrm{the} \mathrm{temperature} \mathrm{of}$ $25^{\circ} \mathrm{C}$ under the load of (a1) $10 \mathrm{~N},(\mathbf{a} 2) 15 \mathrm{~N}$, and (a3) $25 \mathrm{~N}$; and (b) at the temperature of $200{ }^{\circ} \mathrm{C}$ under the load of (b1) $10 \mathrm{~N},(\mathbf{b} 2) 15 \mathrm{~N}$, and (b3) $25 \mathrm{~N}$.

Table 4. The EDS analysis results corresponding to the positions in Figure 10.

\begin{tabular}{ccccccc}
\hline \multirow{2}{*}{ Element, at.\% } & \multicolumn{7}{c}{ Positions } \\
\cline { 2 - 7 } & $\mathbf{a 1}$ & $\mathbf{a 2}$ & $\mathbf{a 3}$ & $\mathbf{b 1}$ & $\mathbf{b 2}$ & $\mathbf{b 3}$ \\
\hline $\mathrm{Cr}$ & 48.32 & 42.71 & 34.96 & 31.25 & 36.7 & 12.7 \\
$\mathrm{~N}$ & 40.27 & 36.84 & 5.49 & 37.53 & 37.93 & 24.65 \\
$\mathrm{O}$ & 3.41 & 9.28 & 7.77 & 10.4 & 13.76 & 14.26 \\
$\mathrm{Fe}$ & 8.32 & 9.43 & 48.05 & 15.94 & 9.2 & 46.96 \\
$\mathrm{~W}$ & 4.27 & 2.95 & 0.71 & 3.07 & 2.93 & - \\
\hline
\end{tabular}

Figure 11 shows the morphology of worn tracks on $2 \mu \mathrm{m}$ CrN coated M50 disks when the tested temperatures were equal or above $315^{\circ} \mathrm{C}$. As shown in Figure 11a1,b1,c1, under a tested load of $10 \mathrm{~N}$, the dominant wear mechanism for the $2 \mu \mathrm{m} \mathrm{CrN}$ coated M50 samples was mild-oxidation wear when the tested temperatures were above $315^{\circ} \mathrm{C}$. In additional, under a tested load of $15 \mathrm{~N}$, the wear of $2 \mu \mathrm{m} \mathrm{CrN}$ coated M50 samples could still be characterized as mild-oxidation wear at the temperature of $315^{\circ} \mathrm{C}$ and $400{ }^{\circ} \mathrm{C}$, as illustrated in Figure 11a2,b2. However, when the tested temperature was elevated to $500{ }^{\circ} \mathrm{C}$, the oxidation layers were stripped from the surface of coating under the applied load of $15 \mathrm{~N}$, as illustrated in Figure 11c2. It should be pointed out that the external load of $15 \mathrm{~N}$ just exceeded the load-bearing limitation of $2 \mu \mathrm{m} \mathrm{CrN} \mathrm{coated} \mathrm{M50} \mathrm{disk} \mathrm{at} \mathrm{the} \mathrm{temperature} \mathrm{of} 500{ }^{\circ} \mathrm{C}$, as shown in Figure $5 \mathrm{c}$,d. While the tested load was increased to $25 \mathrm{~N}$, no obvious oxidation layers were detected after wear tests at temperatures of $315^{\circ} \mathrm{C}, 400{ }^{\circ} \mathrm{C}$ and $500{ }^{\circ} \mathrm{C}$, as illustrated in Figure $11 \mathrm{c} 3, \mathrm{~d} 3, \mathrm{e} 3$. 

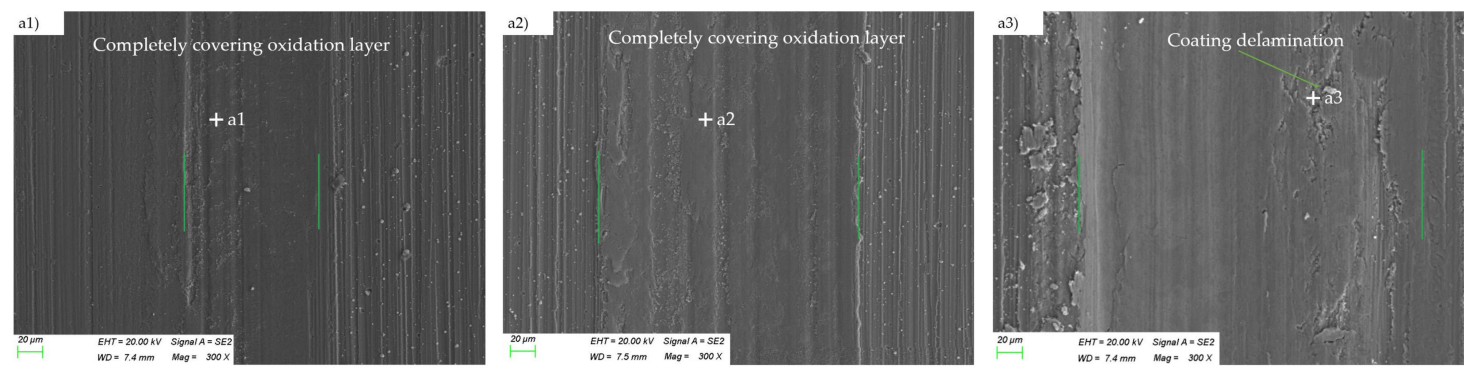

(a)
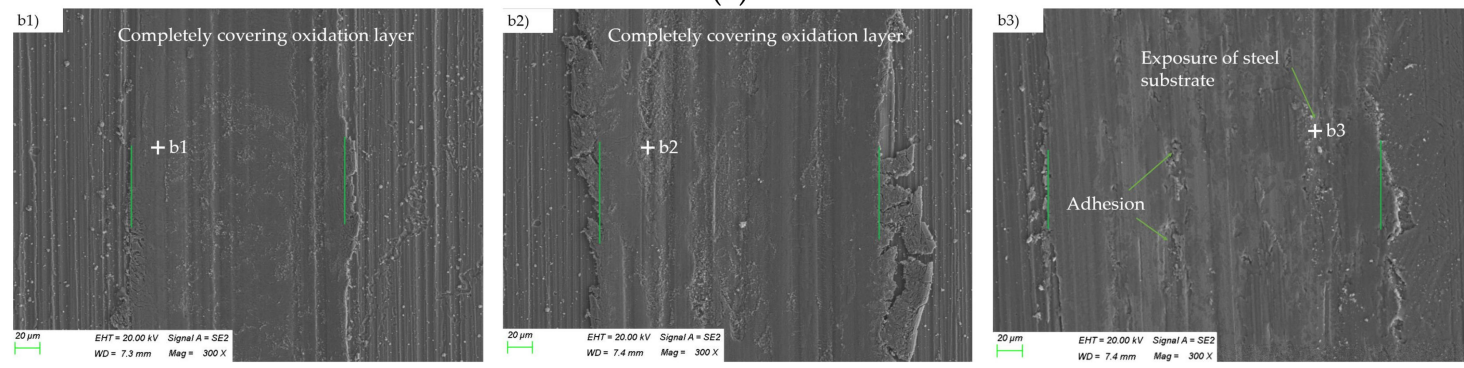

(b)
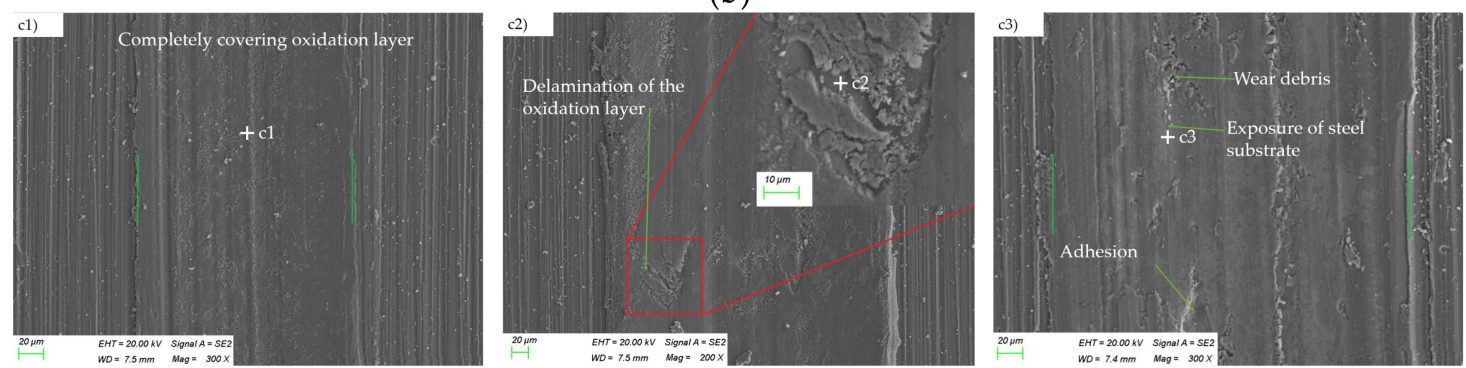

(c)

Figure 11. Morphology of the worn surfaces of $2 \mu \mathrm{m} \mathrm{CrN} \mathrm{coated} \mathrm{M50} \mathrm{disks:} \mathrm{(a)} \mathrm{at} \mathrm{the} \mathrm{temperature} \mathrm{of}$ $315^{\circ} \mathrm{C}$ under the load of (a1) $10 \mathrm{~N},(\mathbf{a} 2) 15 \mathrm{~N}$, and (a3) $25 \mathrm{~N}$; (b) at the temperature of $400{ }^{\circ} \mathrm{C}$ under the load of (b1) $10 \mathrm{~N},(\mathbf{b} 2) 15 \mathrm{~N}$, and (b3) $25 \mathrm{~N}$; and (c) at the temperature of $500{ }^{\circ} \mathrm{C}$ under the load of (c1) $10 \mathrm{~N},($ c2) $15 \mathrm{~N}$, and (c3) $25 \mathrm{~N}$.

EDS analysis results are listed in Table 5. EDS analysis of Points a3, b3, and c3 revealed that the contents of $\mathrm{Fe}, \mathrm{O}$ significantly surpassed that of $\mathrm{Cr}, \mathrm{N}$ in the worn area after 900 cycles of relative sliding under the load of $25 \mathrm{~N}$ at $315{ }^{\circ} \mathrm{C}, 400{ }^{\circ} \mathrm{C}$ or $500{ }^{\circ} \mathrm{C}$. This indicated the severe materials removal occurred for $\mathrm{CrN}$ coatings, thereby leading to exposure of M50 substrate. Besides, it can be noticed that there were delaminated regions and oxidation clusters in a widespread dispersion on the worn tracks. It can be conclude that, at higher tested temperatures, the wear of $\mathrm{CrN}$ coated M50 steel transitioned from mild oxidation wear to the compound wear mechanisms containing oxidative wear, coating delamination or adhesive wear when the external load exceeded its load bearing capacities. This was also the key reason why the high temperature friction coefficient of the $2 \mu \mathrm{m} \mathrm{CrN}$ coated M50 samples suddenly increased under the tested load of $25 \mathrm{~N}$.

Table 5. The EDS analysis results corresponding to the positions in Figure 11.

\begin{tabular}{cccccccccc}
\hline \multirow{2}{*}{ Element, at.\% } & \multicolumn{10}{c}{ Positions } \\
\cline { 2 - 11 } & $\mathbf{a 1}$ & $\mathbf{a 2}$ & $\mathbf{a 3}$ & $\mathbf{b 1}$ & $\mathbf{b 2}$ & $\mathbf{b 3}$ & $\mathbf{c 1}$ & $\mathbf{c 2}$ & $\mathbf{c 3}$ \\
\hline $\mathrm{Cr}$ & 37.48 & 32.19 & 17.92 & 32.65 & 21.61 & 4.9 & 23.58 & 18.3 & 4.0 \\
$\mathrm{~N}$ & 21.93 & 18.67 & 10.45 & 20.97 & 13.72 & 4.53 & 22.68 & 13.85 & 3.47 \\
$\mathrm{O}$ & 34.39 & 35.16 & 36.24 & 39.64 & 44.06 & 35.14 & 44.59 & 40.78 & 31.0 \\
$\mathrm{Fe}$ & 5.52 & 6.22 & 32.76 & 6.61 & 18.75 & 52.79 & 8.48 & 24.87 & 54.79 \\
W & - & - & 1.9 & - & - & 2.15 & - & - & 3.21 \\
\hline
\end{tabular}




\section{Discussion}

The lubricating function of chromium oxide film were further utilized by many researchers to develop the so-called "chameleon" coating for high temperature application, such as $\mathrm{CrN}-\mathrm{Ag}$ [26]. For those $\mathrm{CrN}$ based hard composited coatings, the soft metal possessed solid lubricating function at lower temperatures, while the chromium oxide tribo-layer possessed lubricating function at higher temperatures. It is provn that formed chromium oxide film was found to provide a long endurance and friction coefficients within $0.3-0.4$ at $400-500{ }^{\circ} \mathrm{C}$ in air [27]. This was coincidence with the present study. However, Voevodin et al. [28] argued that, to develop the "chameleon" coating with better temperature-adaptive property, the functional temperature range of soft metal lubricating and chromium oxide film lubricating should be with certain degrees of overlapping. In this study, it was found that the chromium oxide film lubricating started at temperature about $300^{\circ} \mathrm{C}$. Furthermore, we believe that this conclusion would be useful in the $\mathrm{CrN}$ based hard composited coating design.

Many researchers also concerned on the critical load for high temperature application of $\mathrm{CrN}$ coating or $\mathrm{CrN}$ based temperature-adaptive coating. In this study, the high temperature indentation test was employed to study the load bearing capacity of $\mathrm{CrN}$ coating-substrate system, and it was found that the obtained load bearing capacity can be cited as the critical load for high temperature application of $\mathrm{CrN}$ coatings. The failure mechanism of the chromium oxide film is summarized as follows.

Taking the $2 \mu \mathrm{m}$ CrN coated M50 disks as an example, under an external load of $15 \mathrm{~N}$, which just exceeded its load bearing capacity at $500^{\circ} \mathrm{C}$, the stripping and piling up of the oxide film was observed, as illustrated in Figure 11c2. As pointed by Holmberg [29], this kind of thin film failure is related to the tensile fracture and subsequently detachment from the interface. Cracks on the interface were an essential factor triggering this kind of failure. SEM observation verified that radical cracks were generated on the coating surface when the $2 \mu \mathrm{m}$ CrN coated M50 disk was indented under a load of $15 \mathrm{~N}$ at $500{ }^{\circ} \mathrm{C}$ (see Figure 12).

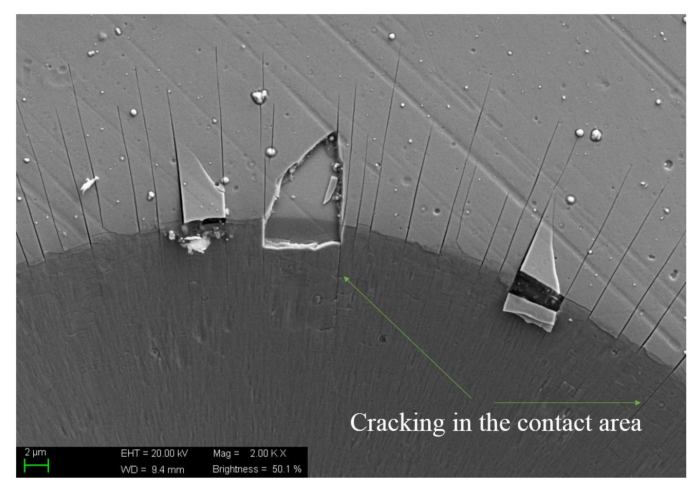

Figure 12. SEM observation of the indented surface of $2 \mu \mathrm{m} \mathrm{CrN} \mathrm{coated} \mathrm{M50} \mathrm{disks} \mathrm{under} \mathrm{a} \mathrm{load} \mathrm{of}$ $15 \mathrm{~N}$ and temperature of $500{ }^{\circ} \mathrm{C}$.

The chromium oxide film would act as a cantilever beam when cracks were on the surface of $\mathrm{CrN}$ coating. The stress concentration would be generated in the center of the cantilever beam, as shown in Figure 13a, thereby resulting in the tensile fracture of the oxide film, as depicted in Figure 13b. Then, shear stress concentration would be generated on the interface between the chromium oxide film and $\mathrm{CrN}$ coating surface. The shear stress concentration finally resulted in the separation of the oxide film from the coating surface, as illustrated in Figure 13c. As the failure of oxidation film occurred, the adhesion between coating material and tribo-counterpart occurred, resulting in the wear transition for $\mathrm{CrN}$ coated M50 steel, as illustrated in Figure 13d. The failure mechanisms for the oxide film was also confirmed by the morphology of wear tracks on $2 \mu \mathrm{m} \mathrm{CrN} \mathrm{coated} \mathrm{M50} \mathrm{disks} \mathrm{at} \mathrm{the} \mathrm{load}$ of $15 \mathrm{~N}$ and temperature of $500{ }^{\circ} \mathrm{C}$, as shown in Figure 13e. 
a)

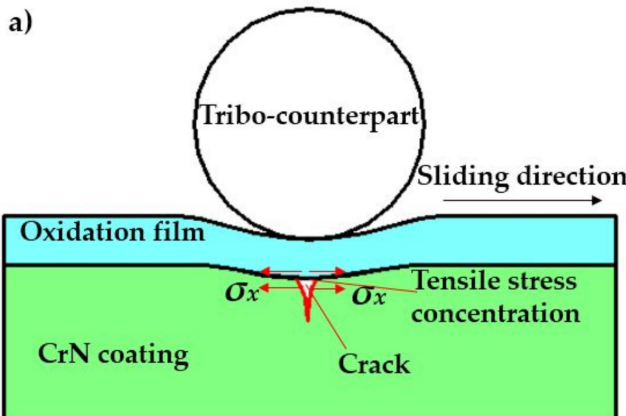

c)
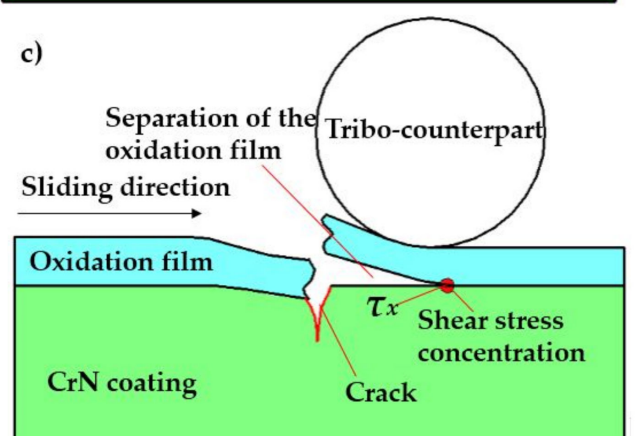

b)

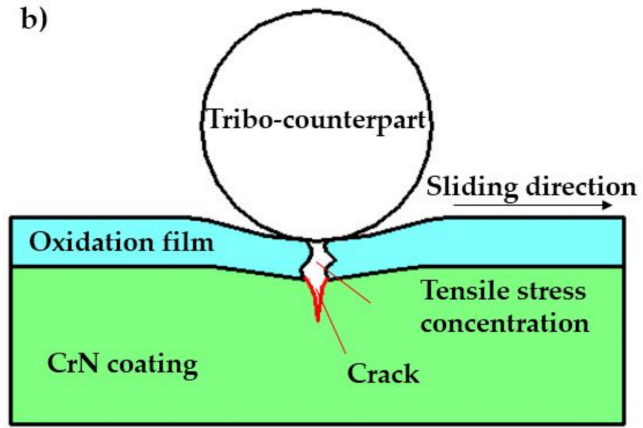

d)

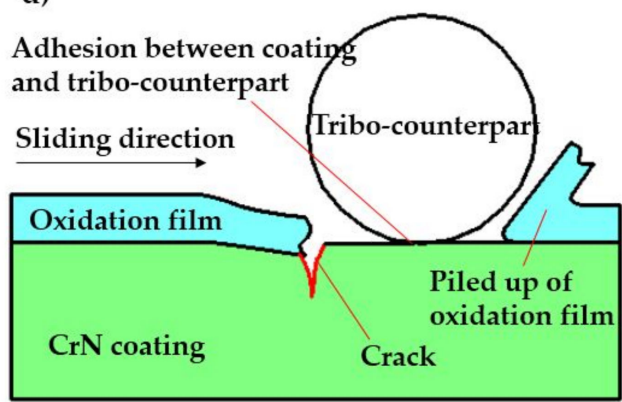

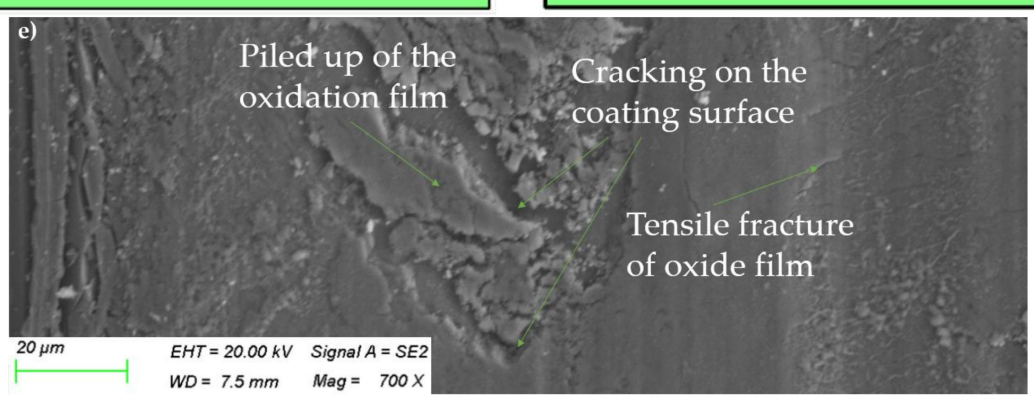

Figure 13. The schematic drawing of the failure of oxidation film: (a) tensile stress concentration; (b) tensile fracture of oxidation film; (c) shear stress concentration; (d) adhesion occurred after the failure of oxidation film; and (e) verification of the failure mechanisms from the wear scar morphologies of the $2 \mu \mathrm{m}$ CrN coated M50 disks under the load of $15 \mathrm{~N}$ and temperature of $500{ }^{\circ} \mathrm{C}$.

In the current study, four types of wear were detected for the $\mathrm{CrN}$ coated M50 disks under various of loads and temperatures: abrasive wear; mild oxidation wear; coating fracture controlled wear; and the compound wear mechanisms containing oxidative wear, coating delamination or adhesive wear. According to the above discussion, the characteristics of wear transition for CrN coated M50 steel at elevated temperatures are summarized in Table 6.

Table 6. Wear transition for $\mathrm{CrN}$ coated M50 steel at elevated temperatures and its characteristics.

\begin{tabular}{ccc}
\hline \multirow{2}{*}{ Temperatures } & \multicolumn{2}{c}{ Load } \\
\cline { 2 - 3 } & Below the Load Bearing Limit & Above the Load Bearing Limit \\
\hline Below $315^{\circ} \mathrm{C}$ & Mild-abrasive wear & Coating fracture controlled wear \\
\hline Equal or above $315^{\circ} \mathrm{C}$ & Mild-oxidation wear & $\begin{array}{c}\text { Compound wear mechanisms containing oxidative } \\
\text { wear, coating delamination and adhesive wear }\end{array}$ \\
\hline
\end{tabular}

\section{Conclusions}

The combination of high temperature spherical indentation and wear test provides a useful and unique way to study the relationships between operating conditions and wear mechanisms of $\mathrm{CrN}$ coating at elevated temperatures. The main conclusions are summarized as follows: 
- The hardness of $\mathrm{CrN}$ coating decrease with temperatures: When the tested temperature was below $315^{\circ} \mathrm{C}$, the hardness of $2 \mu \mathrm{m}$ thick $\mathrm{CrN}$ coating was higher than $5 \mu \mathrm{m}$ thick $\mathrm{CrN}$ coating. However, when the tested temperature was above $400{ }^{\circ} \mathrm{C}$, the $5 \mu \mathrm{m}$ thick $\mathrm{CrN}$ coating had higher values in hardness. A thicker $\mathrm{CrN}$ coating would be helpful in maintaining the stability of surface hardness in high temperatures.

- Wear of $\mathrm{CrN}$ coating changes with external load, $P$, and temperature, $T$ : Under the tested condition of $P<L_{\mathrm{b}}$ and $\mathrm{T}<315^{\circ} \mathrm{C}$, abrasive is the dominant wear mechanism for $\mathrm{CrN}$ coating. With a tested condition of $P<L_{\mathrm{b}}$ and $T \geq 315^{\circ} \mathrm{C}$, wear of $\mathrm{CrN}$ coating transitions into mild oxidation wear due to the lubrication effect of oxidation layers. Under the tested condition of $P>L_{\mathrm{b}}$ and $T<315^{\circ} \mathrm{C}$, wear of $\mathrm{CrN}$ coating was controlled by coating fracture. Under the tested condition of $P>L_{\mathrm{b}}$ and $T \geq 315{ }^{\circ} \mathrm{C}$, wear of $\mathrm{CrN}$ coating transitions into the severe wear mode with a combination of detachment, adhesion and oxidation, due to the tensile fracture of oxidation films, thereby leading adhesion between $\mathrm{CrN}$ coating and tribo-counterpart.

- The presented analysis method can be helpful in predicting the permissible loads for a $\mathrm{CrN}$ coating-M50 substrate system at the given temperature. To conclude, it can be helpful in the tribological design for $\mathrm{CrN}$ coatings and allow the rational selection of coating thickness for a particular high temperature application.

Acknowledgments: This work was supported by the National Natural Science Foundation of China (Grant No. 51675120).

Author Contributions: Guangze Tang contributed the deposition of CrN coatings. Le Gu contributed to the discussion of failure mechanism of chromium oxide film. Yuze Mao contributed to the SEM observation and EDS analysis. Chi Zhang analyzed the test results and wrote the paper.

Conflicts of Interest: The authors declare no conflicts of interest.

\section{References}

1. Gilewicz, A.; Chmielewska, P.; Murzynski, D.; Dobruchowska, E.; Warcholinski, B. Corrosion resistance of $\mathrm{CrN}$ and $\mathrm{CrCN} / \mathrm{CrN}$ coatings deposited using catholic arc evaporation in Ringer's and Hank's solutions. Surf. Coat. Technol. 2016, 299, 7-14. [CrossRef]

2. Podgornik, B.; Sedlaček, M.; Mandrino, D. Performance of CrN coatings under boundary lubrication. Tribol. Int. 2016, 96, 247-257. [CrossRef]

3. Ding, J.; Zhang, T.; Yun, J.M.; Kang, M.C.; Wang, Q.; Kim, K.H. Microstructure, mechanical, oxidation and corrosion properties of the Cr-Al-Si-N Coatings deposited by a hybrid sputtering system. Coatings 2017, 7, 119. [CrossRef]

4. Khanna, R.; Ong, J.L.; Oral, E.; Narayan, R.J. Progress in wear resistant materials for total hip arthroplasty. Coatings 2017, 7, 99. [CrossRef]

5. Ramadoss, R.; Kumar, N.; Dash, S.; Arivuoli, D.; Tyagi, A.K. Wear mechanism of CrN/NbN super lattice coating sliding against various counter-bodies. Int. J. Refract. Met. Hard Mater. 2013, 41, 547-552. [CrossRef]

6. Silva, F.; Martinho, R.; Andrade, M.; Baptista, A.; Alexandre, R. Improving the wear resistance of moulds for the injection of glass fibre-reinforced plastics using PVD coatings: A comparative study. Coatings 2017, 7, 28. [CrossRef]

7. Gouveia, R.M.; Silva, F.J.G.; Reis, P.; Baptista, A.P.M. Machining duplex stainless steel: Comparative study regarding end mill coated tools. Coatings 2016, 6, 51. [CrossRef]

8. Kawahara, Y. An overview on corrosion-resistant coating technologies in biomass/waste-to-energy plants in recent decades. Coatings 2016, 6, 34. [CrossRef]

9. Lim, S.C.; Ashby, M.F. Overview No. 55 wear mechanism maps. Acta Metall. 1987, 35, 1-24. [CrossRef]

10. Wang, Y.; Stephen, M.H. Wear and wear transition mechanisms of ceramics. Wear 1996, 195, 112-122. [CrossRef]

11. Polcar, T.; Parreira, N.M.G.; Novák, R. Friction and wear behaviour of $\mathrm{CrN}$ coating at temperatures up to $500{ }^{\circ} \mathrm{C}$. Surf. Coat. Technol. 2007, 201, 5228-5235. [CrossRef]

12. Qi, Z.; Liu, B.; Wu, Z.; Zhu, F.; Wang, Z.; Wu, C. A comparative study of the oxidation behavior of $\mathrm{Cr}_{2} \mathrm{~N}$ and CrN coatings. Thin Solid Films 2013, 544, 515-520. [CrossRef] 
13. Mandrino, D.; Podgornik, B. XPS investigations of tribofilms formed on CrN coatings. Appl. Surf. Sci. 2017, 396, 554-559. [CrossRef]

14. Scheerer, H.; Hoche, H.; Broszeit, E.; Berger, C. Tribological properties of sputtered CrN coatings under dry sliding oscillation motion at elevated temperatures. Surf. Coat. Technol. 2001, 142-144, 1017-1022. [CrossRef]

15. Beake, B.D.; Fox-Rabinovich, G.D.; Veldhuis, S.C.; Goodes, S.R. Coating optimization for high speed machining with advanced nanomechanical test methods. Surf. Coat. Technol. 2009, 203, 1919-1925. [CrossRef]

16. Smith, J.F.; Zheng, S. High temperature nanoscale mechanical property measurements. Surf. Eng. 2000, 16, 143-146. [CrossRef]

17. Everitt, N.M.; Davies, M.I.; Smith, J.F. High temperature nanoindentation-The importance of isothermal contact. Philos. Mag. 2011, 91, 1221-1244. [CrossRef]

18. Sander, T.; Tremmel, S.; Wartzack, S. A modified scratch test for the mechanical characterization of scratch resistance and adhesion of thin hard coatings on soft substrates. Surf. Coat. Technol. 2011, 206, 1873-1878. [CrossRef]

19. Ghosh, S.; Yadav, S.; Das, G. Ball Indentation Technique: A currently developed tool to study the effect of various heat treatments on the mechanical properties of En24 steel. Mater. Lett. 2008, 62, 3966-3968. [CrossRef]

20. Wheeler, J.M.; Armstrong, D.E.J.; Heinz, W.; Schwaiger, R. High temperature nanoindentation: The state of the art and future challenges. Curr. Opin. Solid State Mater. Sci. 2015, 19, 354-366. [CrossRef]

21. Kim, S.H.; Lee, B.W.; Choi, Y.; Kwon, D. Quantitative determination of contact depth during spherical indentation of metallic materials-A FEM study. Mater. Sci. Eng. A 2006, 415, 59-65. [CrossRef]

22. Puchi-Cabrera, E.S. A new model for the computation of the composite hardness of coated systems. Surf. Coat. Technol. 2002, 160, 177-186. [CrossRef]

23. Kot, M.; Rakowski, W.; Lackner, J.M.; Major, L. Analysis of spherical indentations of coating-substrate systems: Experiments and finite element modeling. Mater. Des. 2013, 43, 99-111. [CrossRef]

24. Huang, X.; Etsion, I.; Shao, T.M. Indentation pop-in as a potential characterization of weakening effect in coating/substrate systems. Wear 2015, 338-339, 325-331. [CrossRef]

25. Mo, J.L.; Zhu, M.H. Sliding tribological behaviors of PVD $\mathrm{CrN}$ and $\mathrm{AlCrN}$ coatings against $\mathrm{Si}_{3} \mathrm{~N}_{4}$ ceramic and pure titanium. Wear 2009, 267,874-881. [CrossRef]

26. Mulligan, C.P.; Papi, P.A.; Gall, D. Ag transport in CrN-Ag nanocomposite coatings. Thin Solid Films 2012, 520, 6774-6779. [CrossRef]

27. Mulligan, C.P.; Blanchet, T.A.; Gall, D. CrN-Ag nanocomposite coatings: High-temperature tribological response. Wear 2010, 269, 125-131. [CrossRef]

28. Voevodin, A.A.; Muratore, C.; Aouadi, S.M. Hard coatings with high temperature adaptive lubrication and contact thermal management: Review. Surf. Coat. Technol. 2014, 257, 247-265. [CrossRef]

29. Matthews, A.; Franklin, S.; Holmberg, K. Tribological coatings: Contact mechanisms and selection. J. Phys. D Appl. Phys. 2007, 40, 5463-5475. [CrossRef]

(C) 2017 by the authors. Licensee MDPI, Basel, Switzerland. This article is an open access article distributed under the terms and conditions of the Creative Commons Attribution (CC BY) license (http://creativecommons.org/licenses/by/4.0/). 